\title{
Comparative Study of Lectin Domains in Model Species: New Insights into Evolutionary Dynamics
}

\author{
Sofie Van Holle ${ }^{1,+}{ }^{\dagger}$, Kristof De Schutter ${ }^{1,2,+}$, Lore Eggermont ${ }^{1}$, Mariya Tsaneva ${ }^{1}$, Liuyi Dang ${ }^{1}$ \\ and Els J. M. Van Damme ${ }^{1, *}$ \\ 1 Department of Molecular Biotechnology, Faculty of Bioscience Engineering, Ghent University, Coupure \\ Links 653, 9000 Ghent, Belgium; Sofie.VanHolle@UGent.be (S.V.H.); Kristof.DeSchutter@UGent.be (K.D.S.); \\ Lore.Eggermont@UGent.be (L.E.); Mariya.Tsaneva@UGent.be (M.T.); Liuyi.Dang@UGent.be (L.D.) \\ 2 Department of Crop Protection, Faculty of Bioscience Engineering, Ghent University, Coupure Links 653, \\ 9000 Ghent, Belgium \\ * Correspondence: elsjm.vandamme@ugent.be; Tel.: +32-9-264-6086 \\ + These authors contributed equally to this work.
}

Academic Editor: Setsuko Komatsu

Received: 6 May 2017; Accepted: 22 May 2017; Published: 25 May 2017

\begin{abstract}
Lectins are present throughout the plant kingdom and are reported to be involved in diverse biological processes. In this study, we provide a comparative analysis of the lectin families from model species in a phylogenetic framework. The analysis focuses on the different plant lectin domains identified in five representative core angiosperm genomes (Arabidopsis thaliana, Glycine max, Cucumis sativus, Oryza sativa ssp. japonica and Oryza sativa ssp. indica). The genomes were screened for genes encoding lectin domains using a combination of Basic Local Alignment Search Tool (BLAST), hidden Markov models, and InterProScan analysis. Additionally, phylogenetic relationships were investigated by constructing maximum likelihood phylogenetic trees. The results demonstrate that the majority of the lectin families are present in each of the species under study. Domain organization analysis showed that most identified proteins are multi-domain proteins, owing to the modular rearrangement of protein domains during evolution. Most of these multi-domain proteins are widespread, while others display a lineage-specific distribution. Furthermore, the phylogenetic analyses reveal that some lectin families evolved to be similar to the phylogeny of the plant species, while others share a closer evolutionary history based on the corresponding protein domain architecture. Our results yield insights into the evolutionary relationships and functional divergence of plant lectins.
\end{abstract}

Keywords: lectin; carbohydrate; evolution; phylogeny; protein domain

\section{Introduction}

Arabidopsis thaliana was the first plant to have its genome completely sequenced in 2000 [1]. More than 60 plant genomes have been published to date, representing species from different lineages of Viridiplantae. The wealth of available completely sequenced plant genomes presents an unrivaled opportunity for comparative analysis and will continue to reveal new aspects of genome biology and evolution. For example, analysis of gene family expansion and evolution across species is employed to identify genes with a shared evolutionary origin. In general, these homologous genes also demonstrate comparable biological functions [2]. The classification of protein-coding genes to known gene families is based on protein sequence similarity. However, a considerable number of genes are "orphans" because they lack homology to any known protein [3]. To date, the extent and role of gene families in plants has only been partially addressed and many gene families remain to be investigated [2]. 
Protein domains are structurally conserved and represent functionally independent components of proteins. The domains themselves have evolved from shorter structural units (e.g., repeats) or by the association of small folding motifs [4,5]. These dominant structural units of proteins are evolutionarily well preserved across taxa [6]. Furthermore, evolutionary events such as duplication, fusion, fission, domain gain and domain loss drive protein domain rearrangements of single-domain proteins and act on the evolution and expansion of multi-domain proteins [7-10]. Not surprisingly, the number of multi-domain architecture families is growing exponentially by the rearrangement and/or combination of existing domains. Conversely, new single-domain architecture families are arising slowly $[9,11]$. Single-domain proteins are therefore more likely to be shared by large groups of species while multi-domain proteins display unique architectures that are more specific, thus accounting for species diversity [11,12]. The formation of multi-domain proteins is an important evolutionary process that gives rise to proteins with new functions explained by their adaptive benefits in response to environmental challenges [13-15].

The plant lectin family encompasses all proteins that selectively recognize and bind to specific carbohydrate structures that occur in a free form or as part of glycoconjugates, such as glycoproteins and glycolipids. The binding of lectins to glycan structures is reversible and does not alter the structure of the glycan moiety [16]. This protein-carbohydrate interaction is involved in a myriad of important processes in the plant such as disease resistance, symbiosis or self-incompatibility. According to their conserved carbohydrate-recognition domain, plant lectins can further be divided into 12 distinct subfamilies: the Agaricus bisporus agglutinin family, the amaranthins, the homologs of class $\mathrm{V}$ chitinases (CRA), the cyanovirin family, the Euonymus europaeus lectin (EUL) family, the Galanthus nivalis agglutinin (GNA) family, the hevein family, the jacalin-related lectin (JRL) family, the legume lectin family, the lysin motif (LysM) family, the Nicotiana tabacum agglutinin (Nictaba) family and the ricin B lectin family [17]. Proteins belonging to a particular plant lectin family are evolutionarily related and the corresponding carbohydrate-recognition domain is defined by its amino acid sequence and the structure of the binding site. Nevertheless, proteins from the same plant lectin family can recognize different carbohydrate structures. These promiscuous carbohydrate-binding sites make it difficult to predict the biological properties of homologous proteins [18-20]. Aside from the classification of plant lectins based on their conserved carbohydrate-recognition domain, lectins can also be grouped according to their expression pattern and subcellular localization. Originally, plant lectins were identified in seeds and the vegetative storage tissues of plants. These lectin genes are constitutively expressed and the corresponding proteins are often synthesized with a signal peptide, guiding them to the secretory pathway. In addition to their role as a storage protein, some of these lectins also play a role in plant defense against pathogens and/or herbivory [21]. More recently, a new class of lectin genes was identified, comprising of inducible lectin genes. Under normal conditions, these proteins are only present at basal levels, but their expression can be induced in response to particular biotic or abiotic stimuli. In contrast to the classical lectins described above, these stress-inducible lectins are located in the nucleocytoplasmic compartments of the plant cell. Some nucleocytoplasmic lectins have been investigated in detail, and are proposed to be involved in stress signaling [22-26].

Although lectins from plants and other species have been an important topic of research for years, most studies dealt with the identification and expansion of a particular lectin family in one species, or specifically focused on one type of lectin motif and its distribution in the plant kingdom [27-36]. To date, there have only been a few publications that report on the distribution of multiple lectin motifs across plant species. Recently, genome wide studies of lectin motifs have been performed in Glycine max (soybean) [37], Cucumis sativus (cucumber) [38], Arabidopsis thaliana (Arabidopsis, thale cress) [39] and Morus notabilis (mulberry) [28]. In this study, a comparative analysis was made of the lectin motifs in several model plants, in particular three important dicot species (soybean, cucumber, Arabidopsis) and the monocots Oryza sativa ssp. japonica and Oryza sativa ssp. indica. The distribution of lectin domains was examined and the phylogenetic relationships of the different plant lectin motifs were investigated. Our comparative study revealed that additional protein domains have recurrently been integrated into 
lectins from multiple plant species. Using a phylogenetic approach, we demonstrated the differential modes of evolutionary innovation and observed compelling differences between the lectin families.

\section{Results and Discussion}

\subsection{Most Plant Lectin Domains Are Widely Distributed in Arabidopsis, Soybean, Cucumber and Rice}

To gain insight into the evolution and diversity of lectin protein architectures across plants, the genomes of Arabidopsis thaliana, Glycine max, Cucumis sativus, Oryza sativa ssp. japonica and Oryza sativa ssp. indica were scanned for the presence of genes encoding plant lectin domains. All predicted lectin domains and any additional protein domains were identified using InterProScan. Altogether, 1337 lectin domain containing sequences were identified, belonging to 10 of the 12 plant lectin families known today (Table 1). Lectin genes belonging to the Agaricus bisporus agglutinin family or the cyanovirin lectin family were not identified in the species under study. Remarkably, the presence of amaranthin lectin genes was confined to the cucumber genome, suggesting that the latter three groups of plant lectins are not widespread in angiosperms. Indeed, cyanovirin homologs were only identified in bacteria, filamentous ascomycetes and the fern Ceratopteris richardii [40]. Similarly, homologs of the Agaricus bisporus agglutinin have only been described in fungi and the liverwort Marchantia polymorpha [41,42]. Members of the amaranthin family have been identified in lower plants (Selaginella moellendorffii) as well as in monocots (maize, barley, wheat, etc.) and in several dicot plants from different families (sugar beet, grape, melon, flax, etc.); demonstrating that this lectin domain is widespread, yet not omnipresent [43,44].

Table 1. Distribution of lectin genes in Arabidopsis, soybean, cucumber and rice.

\begin{tabular}{|c|c|c|c|c|c|c|c|c|c|c|}
\hline \multirow{3}{*}{ Lectin Family } & \multicolumn{10}{|c|}{ Predicted Genes } \\
\hline & \multicolumn{2}{|c|}{$\begin{array}{l}\text { Arabidopsis } \\
\text { Thaliana }\end{array}$} & \multicolumn{2}{|c|}{ Glycine Max } & \multicolumn{2}{|c|}{ Cucumis Sativus } & \multicolumn{2}{|c|}{$\begin{array}{l}\text { Oryza Sativa } \\
\text { (Japonica) }\end{array}$} & \multicolumn{2}{|c|}{$\begin{array}{l}\text { Oryza Sativa } \\
\text { (Indica) }\end{array}$} \\
\hline & $\#$ & $\%$ & $\#$ & $\%$ & $\#$ & $\%$ & $\#$ & $\%$ & $\#$ & $\%$ \\
\hline Amaranthin & 0 & 0.0 & 0 & 0.0 & 16 & 11.0 & 0 & 0.0 & 0 & 0.0 \\
\hline CRA & 9 & 4.2 & 6 & 1.6 & 4 & 2.7 & 2 & 0.6 & 4 & 1.5 \\
\hline EUL & 1 & 0.5 & 3 & 0.8 & 1 & 0.7 & 5 & 1.5 & 5 & 1.8 \\
\hline GNA & 49 & 22.7 & 166 & 45.1 & 45 & 30.8 & 134 & 41.2 & 94 & 34.3 \\
\hline Hevein & 10 & 4.6 & 6 & 1.6 & 4 & 2.7 & 10 & 3.1 & 10 & 3.6 \\
\hline Jacalin & 50 & 23.1 & 5 & 1.4 & 8 & 5.5 & 30 & 9.2 & 33 & 12.0 \\
\hline Legume lectin & 54 & 25.0 & 94 & 25.5 & 29 & 19.9 & 104 & 32.0 & 84 & 30.7 \\
\hline LysM & 12 & 5.6 & 47 & 12.8 & 10 & 6.8 & 20 & 6.2 & 22 & 8.0 \\
\hline Nictaba & 29 & 13.4 & 31 & 8.4 & 20 & 13.7 & 20 & 6.2 & 22 & 8.0 \\
\hline Ricin B & 2 & 0.9 & 10 & 2.7 & 9 & 6.2 & 4 & 1.2 & 4 & 1.4 \\
\hline $\begin{array}{l}\text { Total number of } \\
\text { lectin sequences }\end{array}$ & 216 & & 368 & & 146 & & 329 & & 278 & \\
\hline
\end{tabular}

The total number of identified lectin genes is highly divergent (146-368) when comparing different species, but no correlation was found between the genome size and the number of lectin genes (Table S1). Considering the number of protein-coding transcripts identified for each species, the ratio of lectin genes varies between 0.42 and 0.62. The Arabidopsis and rice genome encompass the highest percentage of lectin genes. It has been demonstrated that whole genome duplications (WGDs) contributed to species diversification and gene expansion [45-48]. All angiosperms have undergone at least two ancient rounds of WGDs which took place in the ancestor of angiosperms and of seeds plants [49]. Subsequently, the Arabidopsis lineage underwent three additional polyploidy events [50], similar to the rice and soybean genome, which independently also have undergone three rounds of WGDs [51-55]. The cucumber genome on the other hand, has only experienced one polyploidy event that is shared by all core eudicots and thus represents a more ancestral genome [56,57]. In spite of 
the differences in the number of WGDs in the four plant species under study, there is no correlation between the occurrence of multiple WGDs and the total number of lectin genes in the different species. Analysis of the distribution of the lectin domains (LysM, GNA, JRL, legume lectin, Nictaba, hevein and ricin B domain) in the PLAZA database [58] revealed the presence of these domains in a wide range of species from lower plants (Physcomitrella patens and Amborella trichopodia) to monocots and dicots.

A comparative analysis of the size of the different plant lectin families (Table 1), demonstrates that the GNA and legume lectin homologs are most abundant. Apart from Arabidopsis, the GNA family is the largest lectin family in all species representing 30-45\% of all lectin sequences. In rice and soybean, the GNA and legume lectin family together account for more than $70 \%$ of all lectin genes. The third largest family is the LysM family $(12.8 \%)$ in soybean, the Nictaba family $(13.7 \%)$ in cucumber and the jacalin family $(9.2 \%)$ in rice. In Arabidopsis, the jacalin family $(23.1 \%)$ is the second largest family after the legume lectin family $(25.0 \%)$, and the GNA family (22.7\%) completes the top three. In this context, PLAZA analyses indicate that a combination of tandem and segmental duplications are responsible for the expansion of these lectin families in Arabidopsis, soybean and rice.

\subsection{Domain Organization of Lectin Genes in Arabidopsis, Soybean, Cucumber and Rice}

Protein domains are the building blocks of all proteins, and the combination of particular protein domains defines protein functionality [59]. Using a combination of InterProScan5 and hidden Markov models, all annotated protein domains were identified in the putative lectin sequences. Table 2 illustrates the most common domain architectures present in Arabidopsis, soybean, cucumber and rice. An enumeration of all identified domain architectures in these species is presented in Table S2.

Protein sequences consisting of multiple lectin domains were found in most lectin families (EUL, hevein, jacalin, legume lectin, LysM, Nictaba and ricin B); though no combinations of different lectin domains within one putative lectin sequence were retrieved. Furthermore, the lectin domains arrayed in tandem can also be linked to additional, unrelated protein domains. Examples are the amaranthin/amaranthin/aerolysin combination in cucumber and the LysM/LysM/protein kinase domain combination that is present in all the species under study. The EUL lectin domain is the only lectin domain that is not present in combination with other annotated protein domains, though proteins composed of two EUL domains arrayed in tandem were identified in rice. These results support previous studies which concluded that in addition to Physcomitrella patens and Selaginella moellendorffii, mainly monocots comprise EUL domains arrayed in tandem while the single-domain proteins are present in both monocot and dicot species [60,61].

Our analysis revealed that almost all lectin domains can occur as single-domain proteins. However, it should be mentioned that in those proteins, the full-length protein sequence does not always consist of the lectin domain alone. The additional $\mathrm{N}$ - or C-terminal sequences are unrelated to the lectin domain, but do not correspond to any known protein domain. The majority of the identified domain architectures represent multi-domain proteins, consisting of one or more lectin domain(s), in combination with other annotated protein domains. Glycosyl hydrolase $(\mathrm{GH})$ domains were found in combination with the hevein domain (GH19), the legume lectin domain (GH1 or GH17) and the ricin B lectin domain (GH5 or GH27). Similarly, the F-box domain was identified in combination with the jacalin, LysM and Nictaba domains in multiple species. Another reoccurring protein domain found in all species is the protein kinase (PK) domain. This protein domain is associated with the CRA, GNA, jacalin, Nictaba, LysM and legume lectin domains in various species.

Furthermore, a lot of unique domain combinations were identified, comprising a lectin domain and one or more additional protein domain(s). The presence of these protein domain architectures is predominantly limited to a particular species, supporting previous observations that long multi-domain architectures tend to be more species-specific. However, a large majority of all plant domain arrangements was shown to be present in all linages; as illustrated in Table 2. Previous investigations revealed that if a protein domain is present in a particular species, there tend to be multiple genes encoding proteins in this domain [12,62]. Based on Table 1, this is also applicable 
to lectin encoding genes with the exception of the EUL family, of which there is only one gene present in the genomes of Arabidopsis and cucumber. Moreover, these studies showed that species without a recent WGD have lower rates of protein rearrangement. This is in agreement with our data as the cucumber genome (the only species in our study without recent WGDs) encompasses the lowest number of species-specific domain combinations (Table S2).

Table 2. Most prevalent domain architectures in Arabidopsis thaliana (At), Glycine max (Gm), Cucumis sativus (Cs) and Oryza sativa ssp. japonica (Os ja) and indica (Os in $)^{1}$. CID: chitinase insertion domain, SG: S-locus glycoprotein, PK: protein kinase, SRK: S-locus receptor kinase, GH: glycoside hydrolase, F-box AD1: F-box associated domain type 1, NB-ARC: nucleotide binding domain shared by Apaf-1, R proteins, and CED-4; TIR: Toll/Interleukin-1 receptor; RIP: ribosome-inactivating protein domain.

\begin{tabular}{|c|c|c|c|c|c|c|}
\hline Domain Architecture & $A t$ & $G m$ & Cs & Os ja & Os in & Schematic Representation \\
\hline Amaranthin/amaranthin/aerolysin & 0 & 0 & 16 & 0 & 0 & - \\
\hline CRA & 2 & 5 & 4 & 2 & 3 & \\
\hline CRA/CID & 7 & 0 & 0 & 0 & 0 & 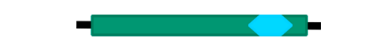 \\
\hline $\mathrm{EUL}_{(1-2)}{ }^{*}$ & 1 & 3 & 1 & 5 & 5 & \\
\hline GNA & 6 & 9 & 3 & 2 & 11 & \\
\hline $\mathrm{GNA}_{\mathrm{SG}_{(0-2)}} / \mathrm{PAN}_{(0-2)} / \mathrm{PK}_{(0-2)} / \mathrm{SRK}_{(0-2)}$ & 43 & 155 & 42 & 125 & 76 & \\
\hline Hevein $_{(1 \text { or } 4)}$ & 0 & 0 & 0 & 2 & 2 & \\
\hline Hevein/barwin & 1 & 2 & 0 & 0 & 0 & $=$ \\
\hline Hevein $_{(1-2)} /$ GH19 & 9 & 4 & 4 & 8 & 8 & \\
\hline $\operatorname{Jacalin}_{(1-4)}$ & 44 & 4 & 5 & 17 & 21 & \\
\hline F-box $_{(0-1)} /$ F-box $\mathrm{AD}_{(0-1)} /$ jacalin & 2 & 1 & 0 & 0 & 0 & \\
\hline $\operatorname{Jacalin}_{(1-2)} / \operatorname{Kelch}_{(1,2 \text { or } 4)}$ & 4 & 0 & 0 & 0 & 0 & \\
\hline${\mathrm{C} 1-\text { like }_{(1-3)} / \mathrm{DC} 1 / \text { jacalin }}$ & 0 & 0 & 3 & 0 & 0 & \\
\hline $\mathrm{PK} /$ jacalin $_{(1-3)}$ & 0 & 0 & 0 & 4 & 1 & 2 \\
\hline Dirigent/jacalin & 0 & 0 & 0 & 4 & 4 & \\
\hline NB-ARC/jacalin $(1-3)$ & 0 & 0 & 0 & 3 & 4 & $\bar{z}$ \\
\hline Legume $_{(1-2)}$ & 13 & 27 & 2 & 18 & 12 & \\
\hline Legume $_{(1-2)} / \mathrm{PK}$ & 41 & 66 & 27 & 79 & 68 & \\
\hline $\operatorname{LysM}_{(1-2)}$ & 6 & 25 & 3 & 12 & 11 & \\
\hline F-box/LysM & 1 & 2 & 1 & 1 & 0 & \\
\hline $\operatorname{LysM}_{(1-2)} / \mathrm{PK}$ & 5 & 18 & 6 & 7 & 10 & \\
\hline Nictaba $_{(1-2)}$ & 7 & 6 & 8 & 4 & 4 & \\
\hline F-box/Nictaba $(1-2)$ & 18 & 25 & 12 & 15 & 16 & \\
\hline TIR/Nictaba & 4 & 0 & 0 & 0 & 0 & \\
\hline GH5/ricin B & 2 & 6 & 4 & 3 & 3 & $=$ \\
\hline GH27/ricin B & 0 & 4 & 0 & 1 & 1 & -1 \\
\hline Ricin B/ricin B & 0 & 0 & 3 & 0 & 0 & - \\
\hline RIP/ricin B/ricin B & 0 & 0 & 2 & 0 & 0 & $=$ \\
\hline
\end{tabular}

${ }^{*}$ Subscript specifies the number of domains (t: 1-2; u: 0-2; v: 1 or $4 ; \mathrm{w}: 1-4 ; \mathrm{x}: 0-1 ; \mathrm{y}: 1,2$ or $\left.4 ; \mathrm{z}: 1-3\right) ;{ }^{1}$ A complete list of all domain combinations is available in Table S2.

\subsection{Phylogenetic Relationships and Biological Significance}

A selection of lectin domains and some reccurring combinations of lectin domains and particular non-lectin protein domains were investigated in more detail. Evolutionary relationships between the protein domains from the different species were investigated by building maximum likelihood trees with RAxML. The results of the phylogenetic analyses and the biological importance of the protein domain combinations are discussed below. 


\subsubsection{Ricin B and GH Domains}

In the genomes of Arabidopsis, soybean, cucumber and rice, the ricin B lectin domain is found to be part of multi-domain proteins; including the combination with a GH27 or a GH5 domain, a second ricin $\mathrm{B}$ domain, or in the $\mathrm{RIP} /$ ricin $\mathrm{B} /$ ricin $\mathrm{B}$ architecture. The maximum likelihood tree built using the protein sequences of all ricin $B$ domains (Figure 1a), clearly reveals the closer relationship of ricin $\mathrm{B}$ domains that occur as part of the same domain architecture. Clade 1 groups together all ricin $\mathrm{B}$ lectin domains that are part of the GH27/ricin B domain architecture. The ricin B lectin domains from the cucumber specific ricin B/ricin B and RIP/ricin B/ricin B architectures (clade 2) are more closely related to each other than to those originating from other domain architectures, indicating that these domain combinations share a common ancestor as already suggested in other studies [63]. Clades 3-7 of the phylogenetic tree group together all the ricin B domains that are fused to a GH5 domain. Notably, within a certain clade, homologs of the same species often share the closest phylogenetic relationship.

Phylogenetic analyses of the GH domains (Figure 1b) support the findings from the ricin B tree. The GH5 and GH27 sequences are clustered in two separate clades (clade 2 and 3, respectively) of the phylogenetic tree, in a similar way to the corresponding ricin B domains in the ricin B tree. What is more, the subbranches are organized analogously (Figure S1), suggesting that the GH and ricin $\mathrm{B}$ domains evolved together and that the $\mathrm{GH} /$ ricin $\mathrm{B}$ domain combinations did not result from a rearrangement of the individual protein domains. Clade 4 contains the GH19 sequences and the unique GH1 sequence from Oryza sativa ssp. indica. Similar to the other clades, the subclades reflect the origin of the retrieved sequences. Surprisingly, the GH1 sequence shows a close connection to two GH19 domain sequences from soybean even though they are not part of the same clan of GHs (available online: www.cazy.org). A separate branch (clade 1) only containing the GH17 sequence from Oryza sativa ssp. japonica completes the phylogenetic tree. In this context, several studies investigated the evolution of glycoside hydrolase subfamilies. However, these reports mainly focused on different GH subfamilies, or were confined to bacterial and/or fungal species. Aspeborg and coworkers analyzed the large GH5 subfamily in plants, and group the GH5/ricin B proteins from Arabidopsis, rice and soybean identified in our study, together in a special cluster (GH5_11) similar to our phylogenetic analysis [64].

The ricin B domain refers to the lectin domain of ricin, a protein identified in Ricinus communis and known for its high toxicity to mammalian and other eukaryotic cells [65]. Ricin is a ribosome-inactivating protein (RIP) composed of an $\mathrm{N}$-glycosidase domain (A chain or RIP domain) and a lectin domain (B chain or ricin B domain) [66]. Multi-domain proteins with this domain architecture are also referred to as type-2 RIPs. The lectin activity of the ricin B domain has been studied extensively and shows specificity towards galactose and $N$-acetylgalactosamine. The toxicity of ricin is mainly attributed to the $\mathrm{N}$-glycosidase domain, though interaction of the lectin domain with galactosylated receptors on the cell surface helps the toxin to enter the cell [67]. The toxicity of some ricin homologs from Abrus precatorius, Sambucus nigra and Viscum album has been confirmed but it should be mentioned that not all proteins are as toxic as ricin [68]. Expression analysis and overexpression of type-2 RIPs provide evidence that these proteins play a role in plant defense of the plant against pathogens (tobacco mosaic virus) and pest insects (caterpillars, aphids) [69-73].

In cucumber, some ricin B lectins composed of two ricin B lectin domains are found. One of these proteins is referred to as XSP30 and was proposed to represent a signaling molecule produced in the xylem parenchyma and pericycle cells of cucumber roots and controlled by gibberellic acid [74]. Although the cucumber RIP/ricin B/ricin B homologs show high sequence similarity with the ricin sequence, their toxicity remains to be investigated [43].

Although GH/ricin B combinations have been identified in several of the species under study, this type of multi-domain protein has not yet been investigated in plants. In bacteria, combinations of such domains have been reported previously, and were shown to be involved in the degradation of insoluble or complex polysaccharides. These GH/ricin B proteins comprise an unusual combination of a carbohydrate-degrading $(\mathrm{GH})$ and a carbohydrate-binding (lectin) domain and in bacterial homologs, 
the latter has been acknowledged to assist the enzymatic activity [75-77]. Both the GH5 and GH27 family are large families of glycoside hydrolases, grouping GHs with diverse enzymatic activities (available online: www.cazy.org) [64,78].

(a)

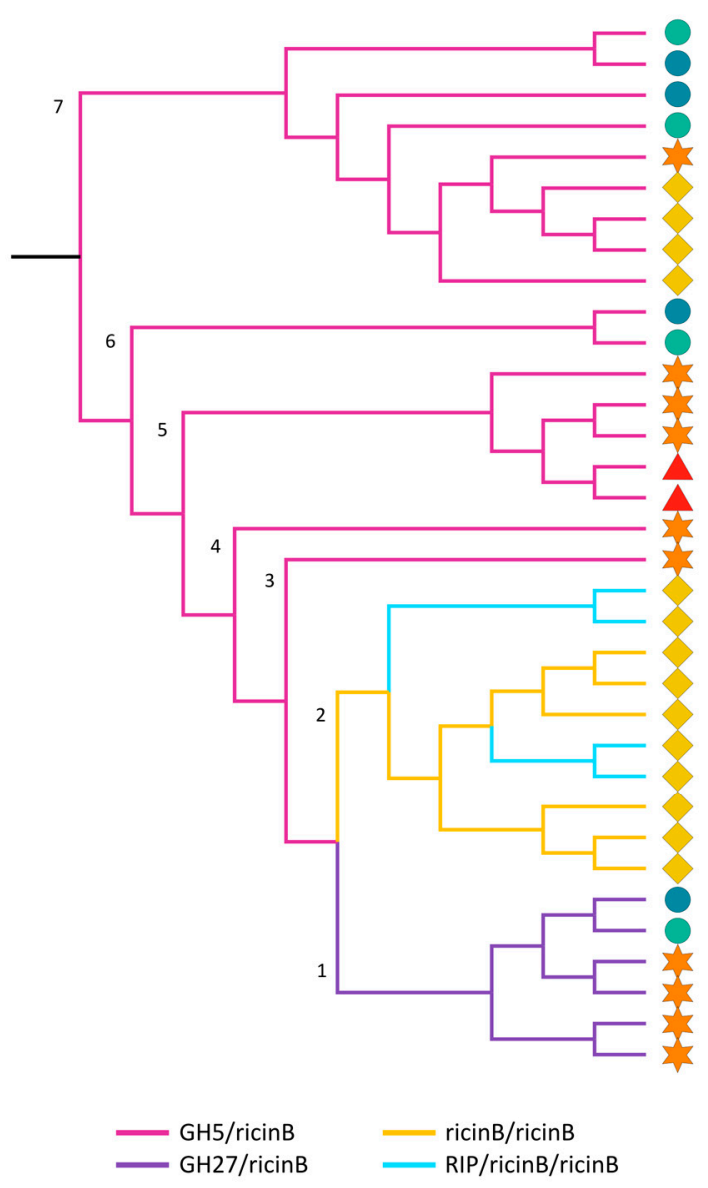

(b)

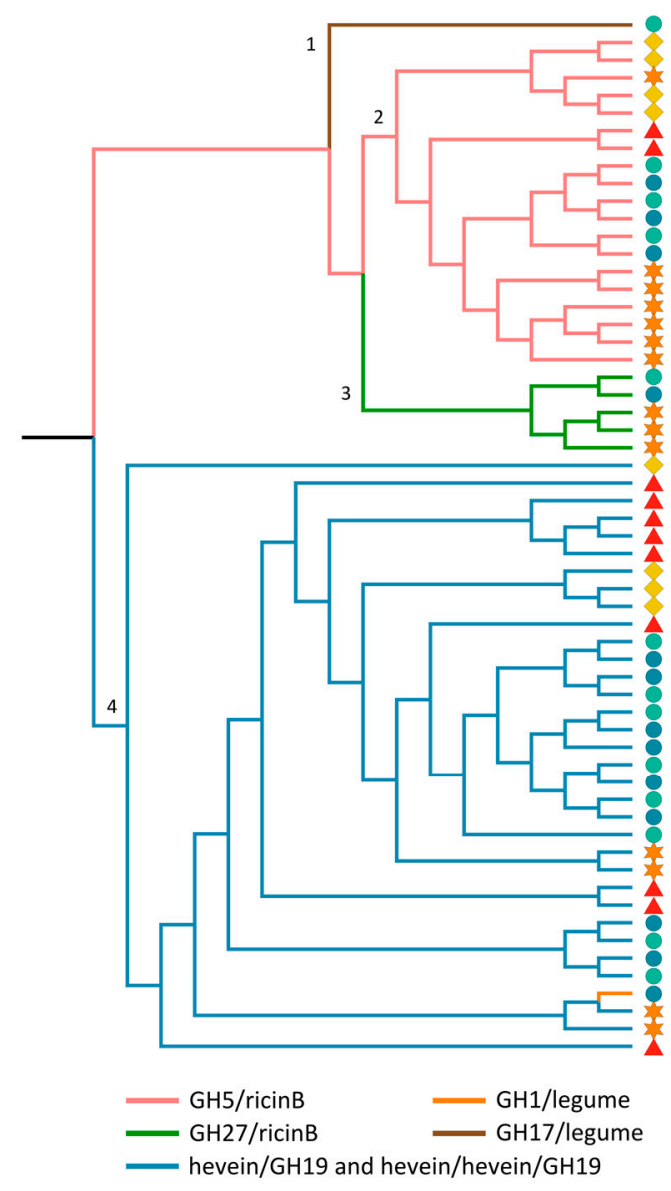

Figure 1. Midpoint rooted cladogram constructed with all ricin B (a) and $\mathrm{GH}(\mathbf{b})$ domain sequences from Arabidopsis (red triangle), soybean (orange star), cucumber (yellow rhomb) and rice (japonica: green circle, indica: blue circle). Numbers indicate the clade numbers and the colored branches correspond to the different domain architectures of the full-length ricin B (a) and GH (b) sequences.

\subsubsection{Nictaba and F-Box Domains}

Proteins containing the Nictaba domain or combinations of an F-box and a Nictaba domain are widespread in plants [30] and were identified in all species under study, with the F-box/Nictaba architecture being the most abundant. The phylogenetic tree built from the Nictaba domains (Figure 2a) reflects the domain organization of Nictaba-containing proteins. There are three clades (clade 1, 3 and 5) containing only sequences representing single-domain proteins. The two smallest clades 3 and 5 encompass exclusively dicot sequences, while the large clade 1 brings together sequences from both monocot and dicot origin. Within this clade, a smaller subclade groups together all Arabidopsis-specific sequences from the TIR/Nictaba domain architecture, implying that these all evolved from a recombination of the TIR and Nictaba in Arabidopsis, followed by multiple duplication events. The Nictaba domain sequence from the unique AIG1/Nictaba architecture is separated in clade 4 of the phylogenetic tree.

Clades 6-9 in the phylogenetic tree are mainly composed of Nictaba domains originating from F-box/Nictaba proteins. Within these clades, a few sequences correspond to single-domain proteins 
only containing the Nictaba domain, possibly due to loss of the F-box domain during evolution. These rearrangements are isolated events and did not always occur in the closest homologs, implying that they took place after the diversification of the different species and/or subspecies. One of the subclades of clade 8 also clusters the sequences derived from PK/Nictaba proteins, a protein domain combination that most probably evolved after the deletion of the F-box domain. Noteworthy, clade 2 with Nictaba sequences originating from the F-box/Nictaba proteins is more separated from the other clades (6-9) containing sequences with the same domain architecture. This clade can be further separated into four subclades: clades $2 \mathrm{c}$ and $2 \mathrm{~d}$ only contain sequences from rice while clades $2 \mathrm{a}$ and $2 \mathrm{~b}$ encompass different dicot sequences. More generally, this organization among subclades also applies to the other subclades of the phylogenetic tree, which also group sequences of the same origin.

Overall, there is a clear separation between the Nictaba domain sequences originating from Nictaba and F-box/Nictaba proteins, indicating that the F-box/Nictaba protein domain combination originated early in a shared ancestor of plants, long before the divergence of monocot and dicot plants. These conclusions are in correspondence with a previous study, in which Nictaba homologs from 15 plant genomes were analyzed [30].

For proteins composed of two Nictaba domains, the individual Nictaba domain sequences are organized in the same (soybean) or closely related (Oryza sativa) clades of the cladogram (Figure S2). This implies that the second domain originated from an in tandem duplication of the original Nictaba domain. For rice, these F-box/Nictaba/Nictaba genes were also later duplicated in the genome. The number of Nictaba homologs in Oryza sativa ssp. japonica and indica is highly comparable since orthologs for each particular sequence always group together in the same subclades of the phylogenetic tree (Figure S2).

For comparison, a phylogenetic tree was also constructed using all F-box domain sequences from the putative lectin proteins (Figures $2 \mathrm{~b}$ and S3). The tree shows more than 15 smaller clades, each mostly containing domain sequence orthologs from one species. Only a small number of clades group together sequences from different species. Clades 1 and 11 contain both monocot and dicot species, one of them (clade 1) brings together sequences from the F-box/F-box AD1/jacalin and F-box/LysM architecture.

Surprisingly, the F-box/F-box AD1/jacalin sequence from Arabidopsis and the F-box/jacalin sequence from soybean (clade 12) are in two distinct clades of the phylogenetic tree, suggesting that they are the result of two independent domain fusion events which could also explain why these sequences are not found in the other species since they do not share a common ancestor in land plants. The F-box sequences from the F-box/LysM and F-box/F-box AD1/jacalin sequences from Arabidopsis and rice also clustered in distinct clades in studies including all F-box sequences present in these species, supporting our results $[79,80]$.

Remarkably, the corresponding F-box domains of the Nictaba domain sequences from clade 2 in Figure $2 \mathrm{a}$ are also found in a distinct clade (11) of the phylogenetic tree based on the F-box domain sequences (Figure $2 b$ ). This again supports the idea that the F-box and Nictaba domain evolved together, and have diverged from an ancestral protein, as suggested in a previous study [30].

Nictaba was originally discovered in tobacco leaves treated with methyl jasmonate [81]. Later, different jasmonate derivatives as well as insect herbivory were reported to specifically enhance the expression of this gene $[82,83]$. Furthermore, Nictaba as well as two Nictaba homologs from soybean exert insecticidal activity. Moreover, Arabidopsis overexpression lines for the Nictaba homologs from soybean also showed reduced disease symptoms upon Pseudomonas syringae infection [84]. Similarly, overexpression of PP2-A1, an Arabidopsis homolog, repressed phloem feeding of Myzus persicae and addition of the protein to an artificial diet significantly reduced the weight gain of aphids $[85,86]$. It is hypothesized that within plant cells, Nictaba acts as a stress signaling molecule through interaction with O-GlcNAc-modified histones [87]. 


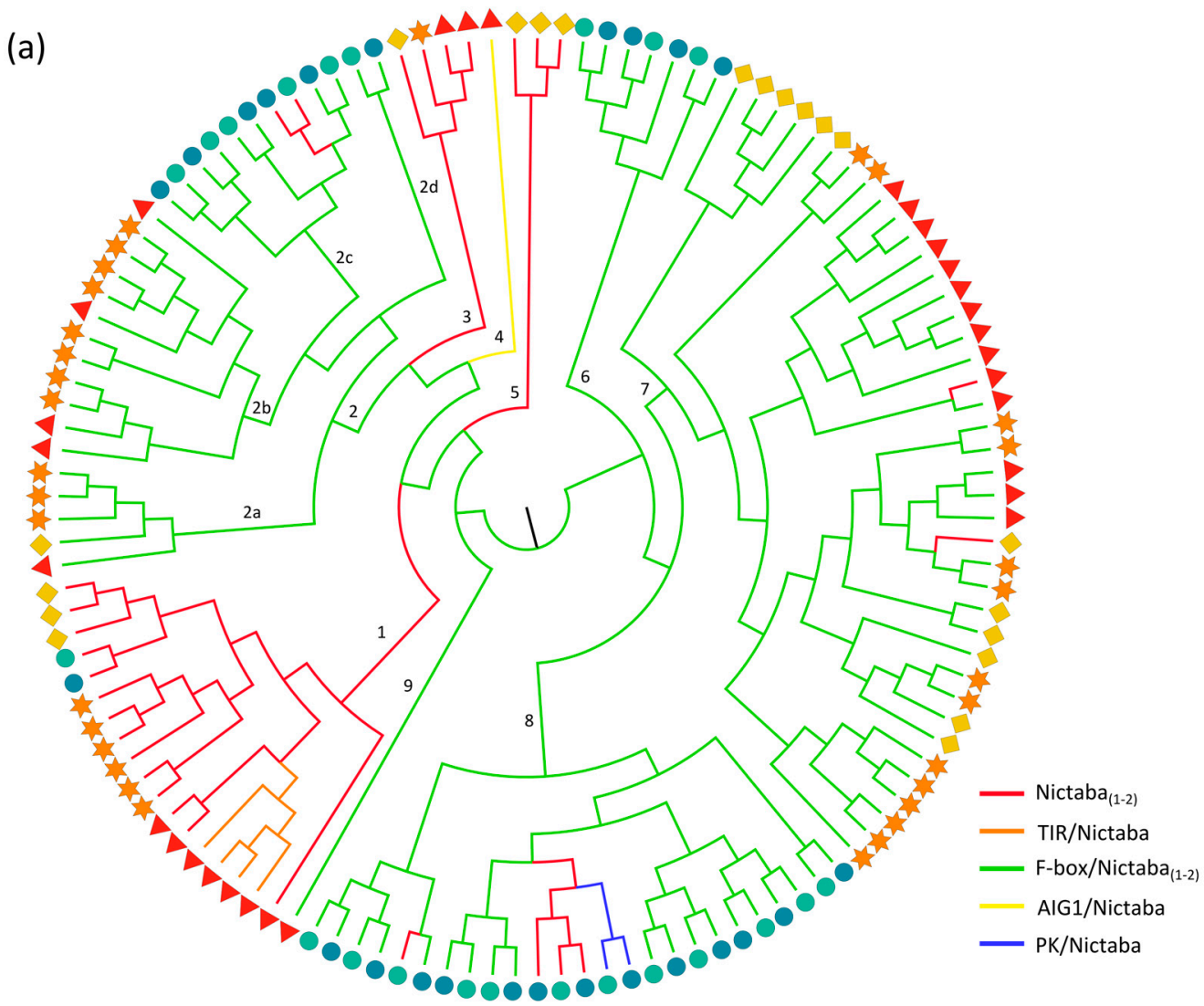

(b)

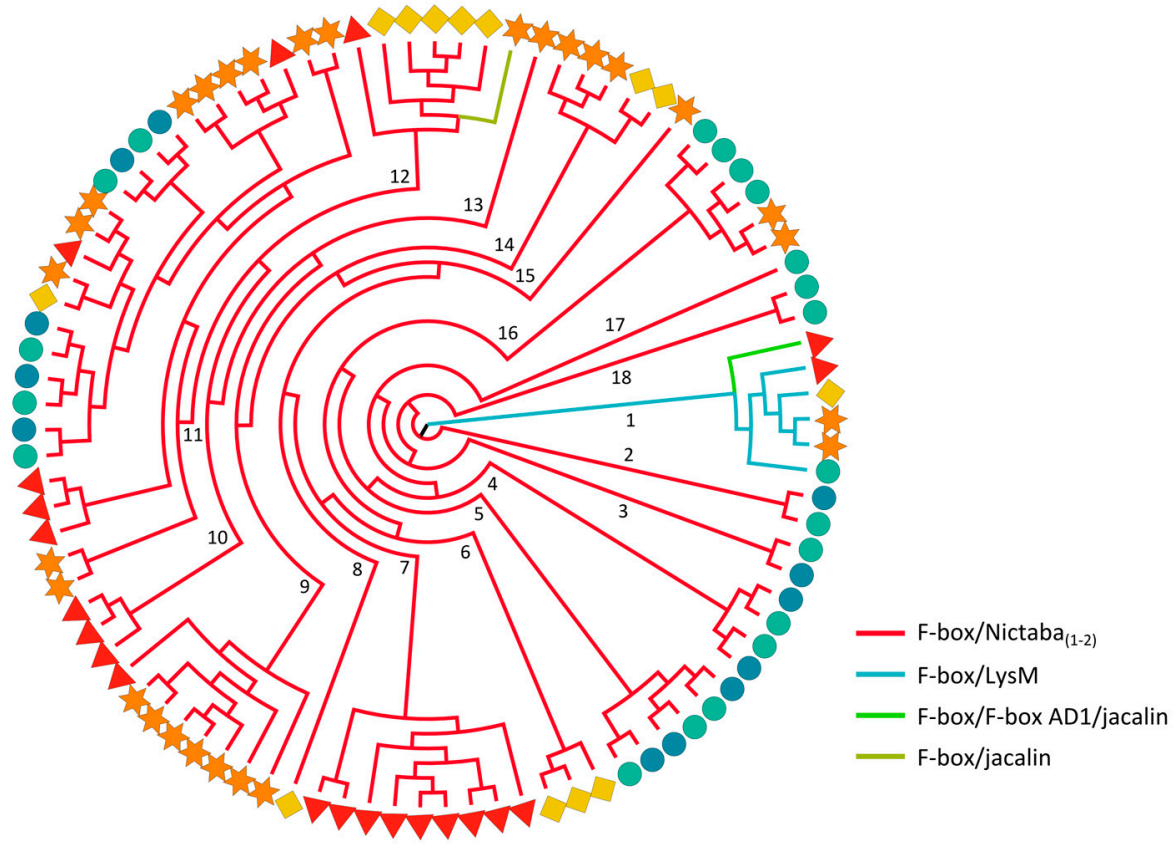

Figure 2. Evolutionary relationships of Nictaba (a) and F-box (b) sequences from Arabidopsis (red triangle), soybean (orange star), cucumber (yellow rhomb) and rice (japonica: green circle, indica: blue circle). The colored branches of the midpoint rooted maximum likelihood tree reflect different domain architectures of the full-length Nictaba (a) and F-box (b) sequences and the numbers specify the clade number. 
In Arabidopsis, some Nictaba domains are found in combination with the TIR or AIG1 (avirulence induced gene 1) G-type domain, which are known for their roles in pathogen detection and defense responses [88,89], again supporting a role of Nictaba proteins in plant defense. However, F-box/Nictaba protein combinations are the most abundant of all Nictaba homologs. The F-box domain is a component of the SCF (Skp, Cullin, F-box) complex, which functions in the proteasome-mediated protein degradation [90-93]. The combination of this protein domain with the carbohydrate-binding Nictaba domain could potentially facilitate degradation of glycoproteins in plants $[79,94]$. Expression analysis revealed that some F-box/Nictaba genes from Arabidopsis and rice are stress inducible $[92,95,96]$. Overexpression lines for two F-box/Nictaba-related genes PP2-B10 and PP2-B11 from Arabidopsis showed a higher tolerance to Pseudomonas syringae infections and high salinity, respectively $[97,98]$, confirming the link between Nictaba homologs and plant stress responses.

\subsubsection{Legume Lectin Homologs}

Phylogenetic analysis of the legume lectin domain sequences (Figure 3) indicates that except for some small clades (containing only 1-11 sequences), none of the other clades group together legume lectin domains originating from the same domain architecture. What is more, the results demonstrate a lineage-wise organization, followed by domain rearrangements within the different lineages. This observation is inconsistent with the phylogenetic analyses of ricin B and Nictaba domains (Figures 1a and 2a), in which the tree was predominantly based on the domain arrangement of the corresponding proteins, underlining that the individual lectin domains have undergone dynamic evolutionary processes. As a result, the different legume lectin domains from a particular species that share a similar domain organization are scattered over distinct branches of the phylogenetic tree. Legume lectin sequences from different organisms are found in some clades, but the closest homologs of Arabidopsis, soybean, cucumber and rice are each clustered together respectively, signifying that the expansion of the legume lectin sequences has occurred after the divergence of the different species. Surprisingly, the phylogenetic tree built using only the PK domain sequences that were found in combination with lectin domains, clusters all PK domains that are part of legume lectin homologs (Figure S5), except for one rice sequence. Previous reports, focusing on these legume-type receptor kinases in Arabidopsis proposed a classification system based on their phylogenetic analyses of the legume lectin, PK and full-length sequences [27,99]. This classification remains consistent with our data, even though our analysis includes four additional genomes (soybean, cucumber, Oryza sativa ssp. japonica and Oryza sativa ssp. indica) (Figure S4).

Legume lectins were originally discovered in leguminous plants. Though legume lectins have been considered as a group of lectins that were restricted to leguminous plants for many decades, compelling evidence now shows that the so-called legume lectin domain is also widespread in the plant kingdom. Legume receptor-like kinases (RLKs) or L-type RLKs are a specific group of legume lectin homologs with diverse functions. Functional characterization of many L-type RLKs reported on the involvement of this type of protein in symbiosis [100-102], defense mechanisms against Phytophthora ssp. [25,103-107], Botrytis cinerea [108], enhanced tolerance against insects [109], bacterial infection [110,111], salinity $[108,112]$ and stomatal closure [111] in multiple plants. Recently, DORN1 encoded by the AtLecRK-I.9 gene was identified as the first receptor for extracellular ATP [113] and recognition of extracellular ATP by this plasma membrane localized L-type RLK induces the innate immune system [114]. 


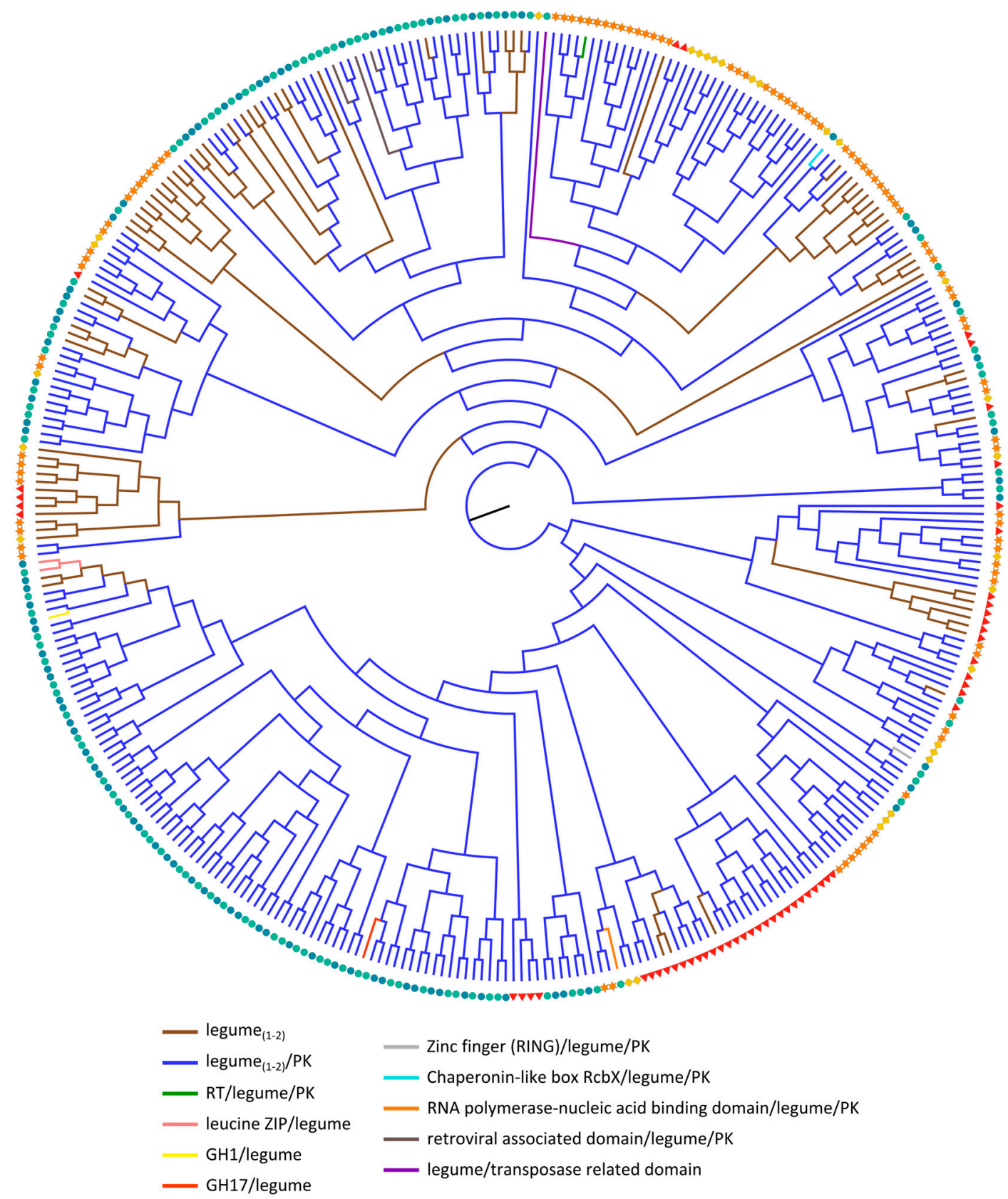

Figure 3. Midpoint rooted cladogram constructed with all legume lectin domain sequences from Arabidopsis (red triangle), soybean (orange star), cucumber (yellow rhomb) and rice (japonica: green circle, indica: blue circle). The colored branches correspond to the different domain architectures of the full-length legume lectin sequences.

\subsubsection{GNA Homologs}

Analysis of the evolutionary relationships of the GNA homologs (Figures 4 and S6) shows resemblance to the data obtained for the legume lectins (Figure 3). The GNA sequences are generally not clustered according to the domain architecture, nor based on the origin of the species from which they were identified. Most of the domain architectures of the GNA proteins are conserved between Arabidopsis, soybean, cucumber and rice, indicating that these multi-domain configurations were established before the divergence of these plant species. Nevertheless, some novel domain arrangements were identified that are mostly specific to rice. The GNA domains from soybean and rice protein sequences make up the largest group of the phylogenetic tree, which can be explained by 
the significant contribution of tandem and segmental duplication in the expansion of the GNA family in soybean [37]. Intriguingly, the expansion of this family in Oryza sativa ssp. indica is less pronounced compared to Oryza sativa ssp. japonica. This is probably the consequence of differential expansion among the two subspecies.

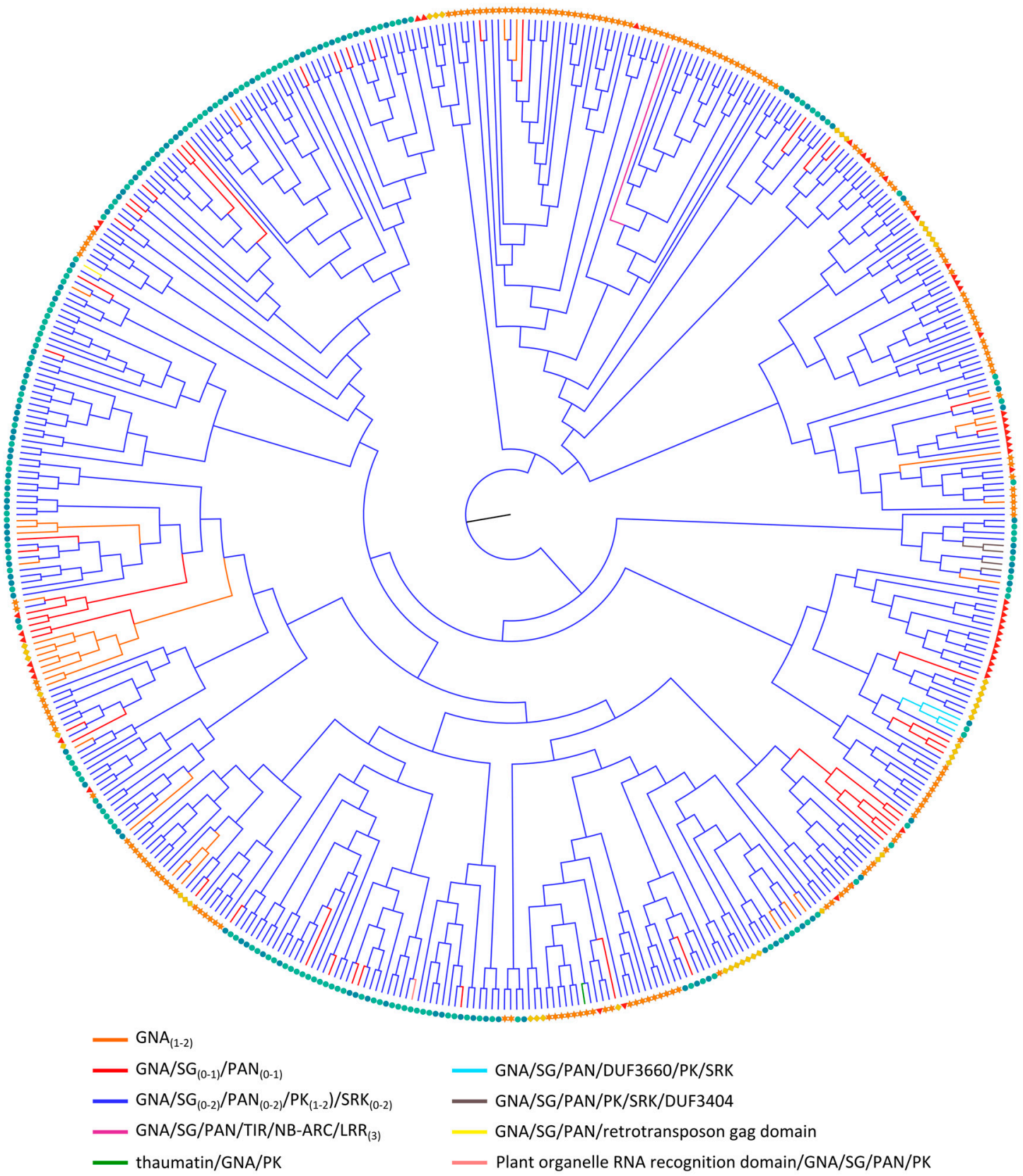

Figure 4. Evolutionary relationships of GNA sequences from Arabidopsis (red triangle), soybean (orange star), cucumber (yellow rhomb) and rice (japonica: green circle, indica: blue circle). The colored branches of the midpoint rooted maximum likelihood tree reflect different domain architectures of the full-length sequences.

All clades contain GNA domain sequences from proteins with the GNA/SG/PAN/PK/SRK domain organization in combination with GNA sequences from other protein configurations. However, the latter, i.e., GNA domains from single-domain proteins, cluster mostly in separate subbranches. The presence of GNA single-domain proteins in clades that are predominantly composed of GNA 
domains from the GNA/SG/PAN/PK/SRK combinations can be explained by recent single-step events in which the PK domain and/or other non-lectin domains were lost. Thus, evidence is accumulating for a large GNA/SG/PAN/PK/SRK family in the common ancestor of flowering plants. Subsequently, this family has further expanded and diverged in the different lineages, resulting in diverse family sizes (Table 1). Notably, most subfamilies are specified by lineage-specific expansions and rearrangements.

Reports on the evolution of the GNA family in literature are limited. One study dealing with GNA RLKs in Brassicaceae concluded that some gene fusion events in the common ancestor of land plants resulted in almost all GNA RLKs, which is in agreement with our hypothesis [33]. Similar assumptions were made in a comparative analysis of protein sequences containing PK domains from Arabidopsis and rice [115]. In this context, Figure S5 again shows that the PK domains from GNA homologs are grouped together in separated branches of the phylogenetic tree. The PK domains present in different lectin sequences are clearly lectin-specific and were not recombined between different lectin domains during evolution.

GNA or G-type RLKs are best studied in Brassicaceae and also known as S-domain RLKs due to the presence of the S-locus glycoprotein domain which is involved in pollen self-incompatibility $[33,116]$. Other G-type RLKs were demonstrated to function in plant defense against both biotic and abiotic stress [24,26,117-119]. So far, there are no reports on the functional analysis of homologs in Arabidopsis, soybean or cucumber. Yet, several genes were shown to be upregulated in plants exposed to diverse stresses [120,121] and one Arabidopsis GNA gene is co-expressed with BIR2, which plays a role in plant innate immunity [122]. OsSIK2, a rice GNA domain containing protein is induced by a broad range of abiotic stresses and overexpression of the gene confers salt and drought tolerance [123]. Another rice protein belonging to the G-type RLK family, OslecRK, is also involved in the plant innate immunity and promotes seed germination [124]. A gene cluster of rice GNA RLKs (OsLecRK1-OsLecRK3) was shown to confer broad-spectrum and durable insect resistance [125]. In a study by Chen and coworkers, transgenic plants carrying a different member of GNA RLKs conferred resistance to Magnaporthe grisea [126].

Other GNA domain architectures including the thaumatin, LRR and NB-ARC domain suggest that these proteins are stress-related given the involvement of these domains in disease resistance and stress adaptation [31,127-130].

\subsubsection{Jacalin-Related Lectin Domains}

Analysis of the phylogenetic relationships between the different jacalin domains reveals that lectin sequences derived from one species show a closer relationship (Figure 5). This is in contrast with the phylogenetic relationships of some other lectin domains (Figures 1a and 2a) where clustering based on the domain architecture was observed. Within the phylogenetic tree, nine clusters can be distinguished. The majority of the jacalin homologs from Arabidopsis group into two separate clusters of the phylogenetic tree (cluster 1 and 9, respectively). Likewise, most jacalin sequences from rice are clustered in clades 2-6. Clade 8 contains sequences of all species. Within this clade, there are several subclades, grouping all the jacalin sequences from cucumber including a subclade with the sequences from the C1-like/divergent C1 (DC1)/jacalin domain architecture. Surprisingly, the three jacalin domains from the Lis homology dimerization domain (LISH dimerization)/CT11-RanBPM C-terminal to LISH (CTLH) / jacalin domain combination are found in different subclades of clade 8, suggesting that these domain repeats do not result from in tandem duplications. The jacalin domain from the GTPase/jacalin domain combination is also part of clade 8 and possibly originates from the fusion of the GTPase domain to an already existing jacalin in rice.

In agreement with the phylogenetic analysis of the F-box protein domains (discussed in 2.3.2), the jacalin domains of the (F-box/)F-box AD1/jacalin proteins from Arabidopsis and the F-box/jacalin protein from soybean cluster in two different branches (clade 1 and 7 , respectively) of the phylogenetic tree. This observation again confirms that these proteins do not share a common history. 


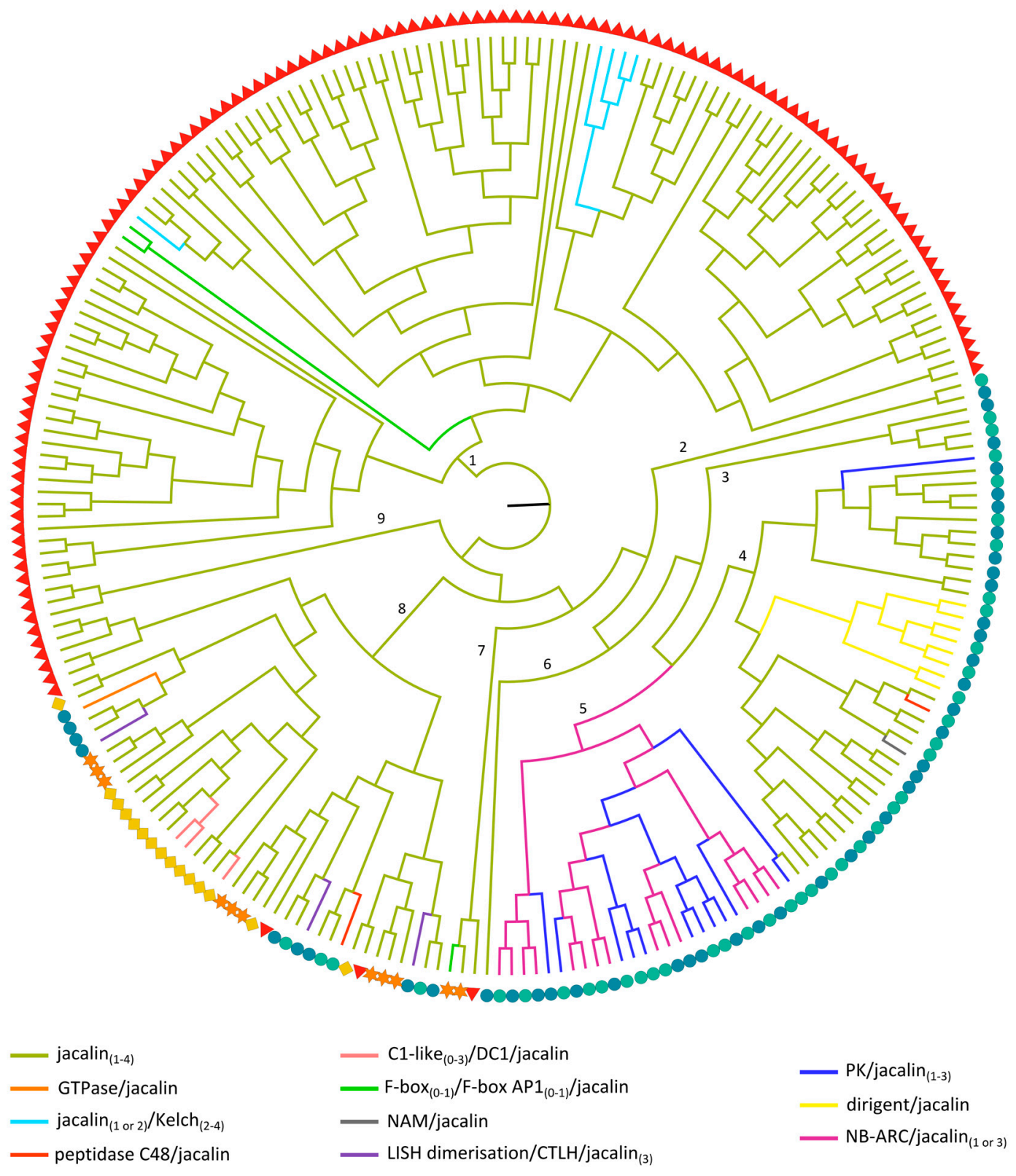

Figure 5. Evolutionary relationships of JRL sequences from Arabidopsis (red triangle), soybean (orange star), cucumber (yellow rhomb) and rice (japonica: green circle, indica: blue circle). The colored branches of the midpoint rooted maximum likelihood tree reflect different domain architectures of the full-length JRL sequences and the numbers specify the clade number.

In clades 2, 3, 6 and 9; only jacalin domains from the single-domain architecture are grouped (Figure S7). All other clades contain jacalin sequences from both the single-domain architecture and multi-domain architectures involving only jacalin domains and multi-domain proteins with additional non-lectin domains. Interestingly, in clade 5, only one jacalin domain from a single domain architecture is found. All other sequences in this clade originate from NB-ARC/jacalin or PK/jacalin architectures, suggesting that the additional non-lectin domain was lost in the earlier described sequence. The close connection between the jacalin domains from the NB-ARC/jacalin and PK/jacalin arrangements indicates that these proteins share a common ancestor. Remarkably, the third jacalin domain from one of the PK/jacalin/jacalin/jacalin protein combinations is grouped in clade 4, signifying a unique and more recent rearrangement. This is not in full agreement with the phylogenetic tree built with all 
PK domain sequences that are part of lectin architectures (Figure S5) in which all PK sequences from jacalin-containing proteins grouped together.

The dirigent/jacalin proteins are restricted to rice and most probably evolved from a recombination of the dirigent and jacalin domain before the diversification of rice. This event was followed by multiple tandem duplication events, resulting in the presence of these jacalin domains in a separate branch of clade 4 .

Clade 4 also contains the jacalin domain from the exclusive no apical meristem (NAM)/jacalin protein and one of the peptidase $\mathrm{C} 48 /$ jacalin-related jacalin domains. The other jacalin domain originating from the same domain architecture is grouped in clade 8 , suggesting that the recombination of the jacalin domain with the peptidase $\mathrm{C} 48$ domain occurred twice, independently of each other.

JRLs can be classified into 2 subgroups: the vacuolar galactose-binding JRLs and the nucleocytoplasmic mannose-binding JRLs [131]. While mannose-specific lectins are widespread in Viridiplantae, the galactose-specific JRL are mainly confined to the Moraceae family. In this study, a small number of JRLs containing a signal sequence were identified in Arabidopsis (3 sequences) and rice (1 sequence). In soybean and cucumber, none of the sequences contains a signal peptide. The sequences from Arabidopsis are composed of two in tandem arrayed jacalin domains and the first and second domain of these sequences cluster closely together in the phylogenetic tree (Figure S7). The same observations were made based on the phylogenetic tree of Arabidopsis JRLs by Eggermont and co-workers [39].

Several JRLs are involved in disease resistance, abiotic stress signaling, wounding and plant defense. This is reflected in the domain architecture of these lectins, where the jacalin domain is fused to domains related to stress response and defense (e.g., dirigent or disease-response domain, leucine rich repeats (LRR), NB-ARC). The combination of a jacalin and dirigent domains has only been reported in Poaceae species [132] and these chimeric lectins were shown to be involved in plant defense [34]. In addition to a role in plant defense, Ver2, a dirigent-JRL from wheat, was shown to be associated with vernalization-induced $O$-GlcNAc signaling and intracellular motility [133].

Next to the chimeric JRLs, also the JRLs solely composed of jacalin domains were reported as stress-related proteins. Transcript levels for the rice gene Orysata are upregulated in response to several stresses (salt stress, senescence, insect infestation and Magnaporthe grisea infection) and hormonal treatments (jasmonic acid and abscisic acid) [134-138]. Recently, this gene was identified in Saltol-1, a major quantitative trait loci related to salt stress [139]. Overexpression of Orysata, also known as SALT, in rice plants improves salinity tolerance [140] and enhances resistance to Magnaporthe grisea infection [141]. The Arabidopsis-related JAX1 was shown to confer broad but specific resistance to potex viruses [142]. Similarly, the Arabidopsis JAC1 homolog prevents systemic infection of the tobacco etch potyvirus, the plum pox virus, and the lettuce mosaic virus [143-146]. The NB-ARC domain is a novel signaling motif found in bacteria and eukaryotes, and is shared between plant resistance gene products and regulators of cell death in animals [147].

Other domains associated with the jacalin domain are annotated to be related to signal transduction. The C1-like and DC1 domain found in cucumber can bind to diacylglycerol [148], a membrane bound lipid secondary messenger. In rice, multi-domain proteins consisting of a jacalin domain with the GTPase domain and GTPase binding domains (LISH and CTLH) were identified. GTPases function as molecular switches in several processes and signaling cascades [149]. However, the precise role of these multi-domain proteins still needs to be elucidated.

\subsubsection{LysM Domains}

The maximum likelihood tree with the LysM domain sequences (Figure 6) reveals some clustering based on the architecture of the corresponding LysM lectin sequences. However, not all clusters with the same architecture are grouped in one branch, suggesting that the different architectures arose several times during evolution. Clade 2 and 4, for example, only group LysM domains from the LysM/PK multi-domain architecture, but LysM domain sequences from this protein architecture 
are also found in all other clades. Clade 1 is the most diverse, containing LysM domains from five different domain architectures. The LysM domains that originate from homologous domain architectures are generally more closely related. However, the LysM domains from the two rice-specific lytic transglycosylase-like soluble lytic transglycosylase (SLT)/LysM proteins are in two different subbranches. The same occurs for the F-box/LysM-related LysM domains: the rice LysM domain from this architecture is found in a distinct subclade while all dicot sequences group together (clade 1). This might be due to further diversification of the rice LysM domain after the split of the monocots and dicots. Next to the LysM and LysM/PK sequences, clade 5 also groups the two EEIG1-EHBP1/LysM-related LysM domain sequences from soybean.

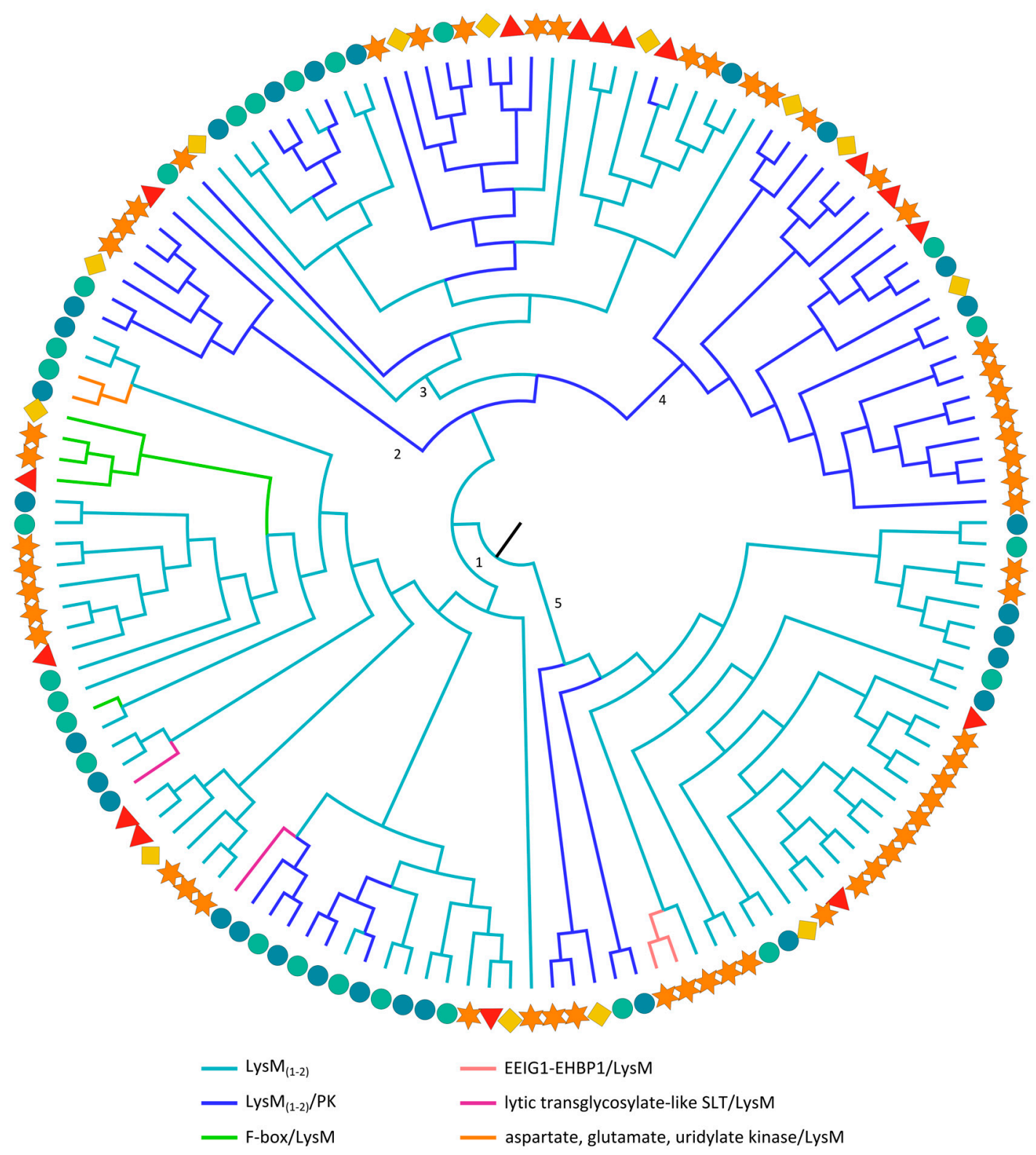

Figure 6. Evolutionary relationships of LysM sequences from Arabidopsis (red triangle), soybean (orange star), cucumber (yellow rhomb) and rice (japonica: green circle, indica: blue circle). The colored branches of the midpoint rooted maximum likelihood tree reflect different domain architectures of the full-length sequences. 
All clades contain LysM domains from all different species, but lineage-specific subclades reveal the expansion through duplication events. Surprisingly, for proteins with two in tandem arrayed LysM domains, the two LysM domains are not clustered in the same clade (Figure S8). While the second LysM domain sequences are grouped in clades 1 and 4, the LysM domains corresponding to domain one are part of clade 3. These observations are in agreement with an earlier study on Arabidopsis LysM lectins [39]. The diversity of LysM motifs was previously reported in the evolutionary studies by Zhang et al. [35,150]. Although these studies focused on the evolution within the different LysM types across all kingdoms, our study focuses on the evolution of the whole LysM family in some core angiosperms.

LysM RLKs are cell wall localized receptors that recognize GlcNAc moieties in various types of bacterial peptidoglycans, fungal chitins and rhizobacterial Nod factors. Some LysM RLKs play a role in plant defense as they are part of the plant innate immunity. Next to the classical LRR receptor kinases, LysM RLKs are now acknowledged as true pattern recognition receptors and are involved in the perception of microbial signals [151,152]. GlcNAc-based elicitors such as lipochitooligosaccharides, chitin and peptidoglycan are perceived by a complex of LysM RLKs. In Arabidopsis, peptidoglycan is recognized by a protein complex including CERK1 (chitin elicitor receptor kinase), a LysM protein with functional intracellular PK domain; and LYM1 or LYM3, LysM homologs that are anchored to the plasma membrane by glycosylphosphatidylinositol (GPI). Analogously, chitin is perceived by CERK1 and LYK5, the latter being a LysM homolog with a dysfunctional kinase domain. The chitin receptor in rice is slightly different since CERK1 associates with CEBiP (chitin elicitor binding protein), a GPI anchored LysM protein. These LysM RLKs are the only lectin pattern recognition receptors for which it has been unambiguously shown that they depend on carbohydrate-lectin interaction for their biological activity $[153,154]$.

Next to their role in plant innate immunity, some LysM RLKs are involved in symbiosis. In legumes and other plants, symbiosis signaling involves recognition of the beneficial microorganisms such as rhizobacteria and mycorrhiza $[152,155,156]$. The receptor complexes of LysM RLKs that perceive the elicitors have been identified in several legumes (Lotus japonica: LjNFR1/LjNRF5, Glycine max: GmNRF1/GmNFR5, Medicago truncatula: LYK3/NFP9) [155,157-161].

\subsubsection{Hevein Domains}

The maximum likelihood tree made using the protein sequences of the hevein domains (Figure 7), uncovers the close phylogenetic relationship of hevein domains that are part of sequences with the same domain arrangement. Clade 1 and 2 group all rice-specific hevein domains from sequences comprising a single or four in tandem arrayed hevein domains, respectively. The hevein domains from the hevein/barwin combination are present in a subclade of clade 3 while the other subclades of clade 3 and clades 4-7 group all hevein domains from the hevein/GH19 or hevein/hevein/GH19 protein architecture. Thus, the hevein/barwin protein most probably originated from a hevein/GH19 protein in which the GH19 domain was exchanged with a barwin domain. The hevein/barwin domain combination is present in many different plant species [16], indicating that this protein rearrangement took place in a common ancestor of land plants and these genes were apparently retained in most lineages. Figure 7 undeniably illustrates that within a certain clade, homologs of a certain species often share the closest phylogenetic relationship. For the Oryza sativa ssp. japonica and indica sequences containing four hevein domains (clade 2), the corresponding hevein domains from both subspecies are clustered together (Figure S9). This is also the case for the two hevein domains from the cucumber hevein/hevein/GH19 sequence that are part of clade 3. For the hevein/GH19 protein sequences, clustering of the GH19 domain sequences (Figure 1b) resembles the organization of subclades in the phylogenetic tree made with the hevein sequences (Figure 7).

Hevein/barwin domain combinations are also known as class I pathogenesis-related (PR) 4 proteins [162]. The barwin domain was originally identified in barley, and plays a role in the defense response against fungal infection [163]. Class I PR 4 genes are generally upregulated upon pathogen 
attack, but other stress factors can also regulate PR 4 transcript levels. In Arabidopsis, the expression of the class I PR 4 gene is upregulated upon ethylene, methyl jasmonate, abscisic acid, high salt treatment and Alternaria brassicicola infection [164-168]. Given the chitin-binding properties of the hevein domain, it is thought that PR 4 proteins contribute to plant defense against fungi [169].

Class I and class IV chitinases consist an N-terminal hevein domain and a C-terminal GH19 catalytic domain [78]. AtEP3, an Arabidopsis homolog of this family, is also considered as a stress-responsive gene since its expression can be upregulated upon Xanthomonas campestris infection, UV light, SA treatment and wounding [170,171]. Analogously, transcript levels of a soybean class I chitinase were also increased in response to Phytophthora sojae infection [172]. RNA-seq analysis demonstrated that two rice class I chitinase genes (CHIT17 and CHIT7) were significantly upregulated in a Magnaporthe oryzae resistant rice cultivar [173]. Transgenic rice plants that overexpress the rice Cht-2 or Cht-3 chitinase gene showed a higher resistance against Magnaporthe grisea [174]. Moreover, the expression of rice class I chitinases $(r c c 2$ or $r c g 3)$ in banana enhanced resistance towards black leaf streak disease [175] and the introduction of another rice homolog $(R C 24)$ in wheat helped the plant to cope with strip rust infection [176].

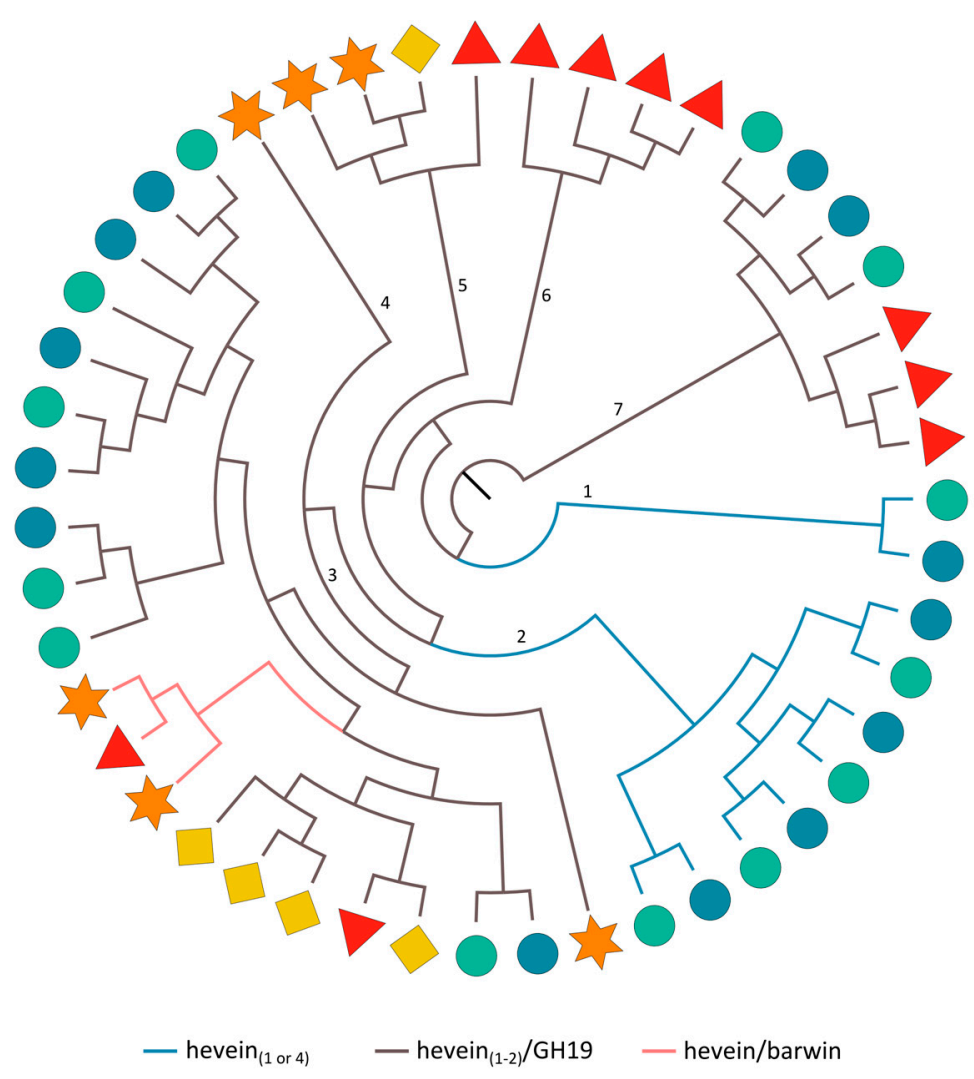

Figure 7. Midpoint rooted cladogram constructed with all hevein domain sequences from Arabidopsis (red triangle), soybean (orange star), cucumber (yellow rhomb) and rice (japonica: green circle, indica: blue circle). Numbers indicate the clade numbers and the colored branches correspond to the different domain architectures of the full-length hevein sequences.

\section{Materials and Methods}

\subsection{Identification and Classification of Lectin Genes}

Putative lectin genes from Arabidopsis, soybean, cucumber and rice were identified using a combination of BLAST, InterProScan 5 and hidden Markov models. Protein sequences encoding a representative protein from each lectin family (for more details, see [37]) were used as a query for 
BLASTp searches (E-threshold: 10, comparison matrix: BLOSUM62, word length: 3). BLASTp was performed with the Arabidopsis (TAIR annotation release 10) and soybean (Wm82.a2.v1) datasets available from Phytozome v. 10 (available online: https:/ / phytozome.jgi.doe.gov/pz/portal.html). The Cucurbit Genomics Database (available online: http://www.icugi.org/cgi-bin/ICuGI/index.cgi) and MSU Rice Genome Annotation Project Database (RGAP release 7) [177] and Phytozome v. 10 were used to perform BLASTp searches for cucumber and rice, respectively. Lectin genes in the genome of Oryza sativa ssp. indica (ASM465v1) were identified using Ensembl Plants (available online: http://plants.ensembl.org/index.html). Subsequently, the top hit was used for a second BLASTp search and all retrieved sequences were selected as candidate lectin genes. The corresponding protein sequences were downloaded and the presence of the lectin domains and any other annotated protein domains was identified using InterProScan5 (available online: http://www.ebi.ac.uk/Tools/webservices/services/pfa/iprscan5_soap) with default settings [178]. Protein sequences that lacked conserved lectin domains were removed from the dataset. The presence of signal peptides and transmembrane domains was analyzed with the SignalP 4.1 Server [179] and the TMHMM Server v. 2.0 [180], respectively.

\subsection{Phylogenetics}

Maximum likelihood trees were generated using the amino acid sequences of the protein domains. For protein sequences containing multiple domains of the same type, the domains were separated and all domain sequences were included in the analysis. The domain sequences were aligned with MUSCLE using default settings [181]. The alignment was performed online (available online: http:/ /www.ebi. ac.uk/Tools/msa/muscle/) or locally using molecular evolutionary genetics analysis 7 (MEGA7) [182]. Subsequently, the aligned sequences were trimmed to generate blocks of conserved aligned sequences using the automated1 option of trimAl v. 3 [183]. Based on the trimmed alignments, maximum likelihood trees were built with RAxML v. 8.2.4 [184]. RAxML used the general time reversible gamma (GTRGAMMA) model with automated determination of the best amino acid substitution model, random number seed and distinct starting trees. Bootstrap iterations to assess the robustness of the generated trees were decided automatically. Phylogenetic trees were visualized and edited with FigTree v. 1.4.2 (available online: http://tree.bio.ed.ac.uk/software/figtree/).

\subsection{Segmental and Tandem Duplications}

Gene expansion through segmental and/or tandem duplications was analyzed with PLAZA [58].

\section{Conclusions}

In this study we presented an inventory of the lectin sequences in five genomes of model plants, including Arabidopsis thaliana, Glycine max, Cucumis sativus, Oryza sativa ssp. japonica and Oryza sativa ssp. indica. Our data demonstrated that most plant lectin families are present across all surveyed genomes. Although these findings are consistent with previous analyses made in dicot genomes, we are not aware of genome wide studies investigating the lectin sequences from monocot species. Furthermore, PLAZA analysis confirmed that all plant lectins under study are also present in Amborella trichopodia and Physcomitrella patens, signifying ancient lectin domain integrations and pointing out the occurrence and importance of lectins throughout the whole plant kingdom.

Additionally, we performed a comparative and evolutionary genomics study of some particular plant lectin domains and some other protein domains that are found in combination with the lectin domains. A detailed analysis of the lectin sequences revealed a wide range of domain architectures, involving the fusions of lectin domains with other annotated protein domains. Parts of these reccurring additional protein domains have been reported to be involved in plant defense, signaling and/or development, which agrees with the idea that lectin domains play a role in plant growth and defense. Some of the multi-domain proteins are widespread, indicating the retention of ancient fusions in a common ancestor. In contrast, the many species-specific domain arrangements can be explained by 
lineage-specific retention of a certain domain rearrangement or by a recent event of protein domain fusion or domain loss in a particular species [12].

For some lectin families, there is significant variation in the number of lectin genes across flowering plants. Phylogenetics confirmed that duplication events and speciation are the driving source for this diversification. This is also reflected in the organization of lectin sequences in the phylogenetic trees. The JRL family clearly demonstrates a lineage-specific evolution while the ricin B family experienced extension of the different domain architectures in most species. These findings support the dynamic evolution of the different plant lectin families in respect to the domain organization and duplication events. In the future, it will be important to continue studying lectin families across species to enrich our understanding of their evolutionary history, but this method also has some limitations. The proteins encoded by the lectin genes are part of a larger and complex interactome, and it will be difficult to relate the emergence of a new protein domain combination to existing pathways. Therefore, a combined analysis of these traditional approaches in combination with co-expression networks would be advantageous and could expand our knowledge since recent studies demonstrated that co-expression networks are conserved also across species [185,186]. At the same time, we cannot exclude the presence of minor mistakes in our dataset due to missing annotation of genes or unidentified protein domains.

It is clear that plants have a large variety of plant lectins at their disposal. During evolution, new lectin domain combinations have been created and used to the benefit of the plant to allow rapid adaptation to changing environmental conditions. Although the functionality of the putative lectin domains needs to be confirmed by experimental evidence, these lectins will most probably exert complementary activities since they are present in different subcellular/tissue specific locations and recognize different carbohydrate structures, either present in the plant or part of pathogens. Further functional investigation of these lectins will substantially contribute to our knowledge of the lectin complement and their importance for the plant.

Supplementary Materials: Supplementary materials can be found at www.mdpi.com/1422-0067/18/6/1136/s1.

Acknowledgments: This work was supported by grants from the Research Council of Ghent University (project BOF15/GOA/005) and the Fund for Scientific Research-Flanders (FWO Grant G006114N). Liuyi Dang acknowledges support from the China Scholarship Council. The authors thank Bruno Verstraeten for his support with RAxML.

Author Contributions: All authors designed and performed the experiments: Lore Eggermont contributed to the analysis of the lectin gene sequences from Arabidopsis; Sofie Van Holle analyzed all lectin sequences from soybean; Kristof De Schutter and Mariya Tsaneva performed the analyses for the rice genomes, and Liuyi Dang investigated the cucumber genome; Sofie Van Holle and Kristof De Schutter performed and analyzed the phylogenetic data; Els J. M. Van Damme conceived and supervised the study; Sofie Van Holle, Kristof De Schutter and Els J. M. Van Damme wrote the paper; all authors read, revised, and approved the manuscript.

Conflicts of Interest: The authors declare no conflict of interest.

\section{References}

1. Arabidopsis Genome Initiative. Analysis of the genome sequence of the flowering plant Arabidopsis thaliana. Nature 2000, 408, 796-815.

2. Martinez, M. Plant protein-coding gene families: Emerging bioinformatics approaches. Trends Plant Sci. 2011, 16, 558-567. [CrossRef] [PubMed]

3. Khalturin, K.; Hemmrich, G.; Fraune, S.; Augustin, R.; Bosch, T.C.G. More than just orphans: Are taxonomically-restricted genes important in evolution? Trends Genet. 2009, 25, 404-413. [CrossRef] [PubMed]

4. Lupas, A.N.; Ponting, C.P.; Russell, R.B. On the evolution of protein folds: Are similar motifs in different protein folds the result of convergence, insertion, or relics of an ancient peptide world? J. Struct. Biol. 2001, 134, 191-203. [CrossRef] [PubMed]

5. Andrade, M.A.; Perez-Iratxeta, C.; Ponting, C.P. Protein repeats: Structures, functions, and evolution. J. Struct. Biol. 2001, 134, 117-131. [CrossRef] [PubMed] 
6. Copley, R.R.; Doerks, T.; Letunic, I.; Bork, P. Protein domain analysis in the era of complete genomes. FEBS Lett. 2002, 513, 129-134. [CrossRef]

7. Kummerfeld, S.K.; Teichmann, S.A. Relative rates of gene fusion and fission in multi-domain proteins. Trends Genet. 2005, 21, 25-30. [CrossRef] [PubMed]

8. Weiner, J.; Beaussart, F.; Bornberg-Bauer, E. Domain deletions and substitutions in the modular protein evolution. FEBS J. 2006, 273, 2037-2047. [CrossRef] [PubMed]

9. Moore, A.D.; Björklund, Å.K.; Ekman, D.; Bornberg-Bauer, E.; Elofsson, A. Arrangements in the modular evolution of proteins. Trends Biochem. Sci. 2008, 33, 444-451. [CrossRef] [PubMed]

10. Moore, A.D.; Bornberg-Bauer, E. The dynamics and evolutionary potential of domain loss and emergence. Mol. Biol. Evol. 2012, 29, 787-796. [CrossRef] [PubMed]

11. Levitt, M. Nature of the protein universe. Proc. Natl. Acad. Sci. USA 2009, 106, 11079-11084. [CrossRef] [PubMed]

12. Kersting, A.R.; Bornberg-Bauer, E.; Moore, A.D.; Grath, S. Dynamics and adaptive benefits of protein domain emergence and arrangements during plant genome evolution. Genome Biol. Evol. 2012, 4, 316-329. [CrossRef] [PubMed]

13. Björklund, Å.K.; Ekman, D.; Light, S.; Frey-Skött, J.; Elofsson, A. Domain rearrangements in protein evolution. J. Mol. Biol. 2005, 353, 911-923. [CrossRef] [PubMed]

14. Vogel, C.; Teichmann, S.A.; Pereira-Leal, J. The relationship between domain duplication and recombination. J. Mol. Biol. 2005, 346, 355-365. [CrossRef] [PubMed]

15. Bashton, M.; Chothia, C. The generation of new protein functions by the combination of domains. Structure 2007, 15, 85-99. [CrossRef] [PubMed]

16. Van Damme, E.J.M.; Peumans, W.J.; Barre, A.; Rougé, P. Plant lectins: A composite of several distinct families of structurally and evolutionary related proteins with diverse biological roles. CRC Crit. Rev. Plant Sci. 1998, 17, 575-692. [CrossRef]

17. Van Damme, E.J.M.; Lannoo, N.; Peumans, W.J. Plant lectins. Adv. Bot. Res. 2008, 48, 107-209.

18. Fouquaert, E.; Smith, D.F.; Peumans, W.J.; Proost, P.; Balzarini, J.; Savvides, S.N.; Van Damme, E.J.M. Related lectins from snowdrop and maize differ in their carbohydrate-binding specificity. Biochem. Biophys. Res. Commun. 2009, 380, 260-265. [CrossRef] [PubMed]

19. Fouquaert, E.; Van Damme, E.J.M. Promiscuity of the Euonymus carbohydrate-binding domain. Biomolecules 2012, 2, 415-434. [CrossRef] [PubMed]

20. Stefanowicz, K.; Lannoo, N.; Proost, P.; Van Damme, E.J.M. Arabidopsis F-box protein containing a Nictaba-related lectin domain interacts with $\mathrm{N}$-acetyllactosamine structures. FEBS Open Bio 2012, 2, 151-158. [CrossRef] [PubMed]

21. Peumans, W.J.; Van Damme, E.J.M. Lectins as plant defense proteins. Plant Physiol. 1995, 109, $347-352$. [CrossRef] [PubMed]

22. Van Hove, J.; De Jaeger, G.; De Winne, N.; Guisez, Y.; Van Damme, E.J.M. The Arabidopsis lectin EULS3 is involved in stomatal closure. Plant Sci. 2015, 238, 312-322. [CrossRef] [PubMed]

23. Xiang, Y.; Song, M.; Wei, Z.; Tong, J.; Zhang, L.; Xiao, L.; Ma, Z.; Wang, Y. A jacalin-related lectin-like gene in wheat is a component of the plant defence system. J. Exp. Bot. 2011, 62, 5471-5483. [CrossRef] [PubMed]

24. Sun, X.L.; Yu, Q.Y.; Tang, L.L.; Ji, W.; Bai, X.; Cai, H.; Liu, X.F.; Ding, X.D.; Zhu, Y.M. GsSRK, a G-type lectin S-receptor-like serine/threonine protein kinase, is a positive regulator of plant tolerance to salt stress. J. Plant Physiol. 2013, 170, 505-515. [CrossRef] [PubMed]

25. Wang, Y.; Weide, R.; Govers, F.; Bouwmeester, K. L-type lectin receptor kinases in Nicotiana benthamiana and tomato and their role in Phytophthora resistance. J. Exp. Bot. 2015, 66, 6731-6743. [CrossRef] [PubMed]

26. Kim, N.H.; Lee, D.H.; Choi, D.S.; Hwang, B.K. The pepper GNA-related lectin and PAN domain protein gene, CaGLP1, is required for plant cell death and defense signaling during bacterial infection. Plant Sci. 2015, 241, 307-315. [CrossRef] [PubMed]

27. Hofberger, J.A.; Nsibo, D.L.; Govers, F.; Bouwmeester, K.; Schranz, M.E. A complex interplay of tandemand whole-genome duplication drives expansion of the L-type lectin receptor kinase gene family in the Brassicaceae. Genome Biol. Evol. 2015, 7, 720-734. [CrossRef] [PubMed]

28. Saeed, B.; Baranwal, V.K.; Khurana, P. Identification and expression profiling of the lectin gene superfamily in mulberry. Plant Genome 2016, 9. [CrossRef] [PubMed] 
29. Sabotič, J.; Ohm, R.A.; Künzler, M. Entomotoxic and nematotoxic lectins and protease inhibitors from fungal fruiting bodies. Appl. Microbiol. Biotechnol. 2016, 100, 91-111. [CrossRef] [PubMed]

30. Van Holle, S.; Rougé, P.; Van Damme, E.J.M. Evolution and structural diversification of Nictaba-like lectin genes in food crops with a focus on soybean (Glycine max). Ann. Bot. 2017, 119, 901-914. [CrossRef] [PubMed]

31. Sharma, S.; Pandey, A.K.; Singh, K.; Upadhyay, S.K. Molecular characterization and global expression analysis of lectin receptor kinases in bread wheat (Triticum aestivum). PLoS ONE 2016, 11, e0153925.

32. Yang, Y.; Labbé, J.; Muchero, W.; Yang, X.; Jawdy, S.S.; Kennedy, M.; Johnson, J.; Sreedasyam, A.; Schmutz, J.; Tuskan, G.A.; Chen, J.G. Genome-wide analysis of lectin receptor-like kinases in Populus. BMC Genom. 2016, 17, 699. [CrossRef] [PubMed]

33. Xing, S.; Li, M.; Liu, P. Evolution of S-domain receptor-like kinases in land plants and origination of S-locus receptor kinases in Brassicaceae. BMC Evol. Biol. 2013, 13, 69. [CrossRef] [PubMed]

34. Song, M.; Xu, W.; Xiang, Y.; Jia, H.; Zhang, L.; Ma, Z. Association of jacalin-related lectins with wheat responses to stresses revealed by transcriptional profiling. Plant Mol. Biol. 2014, 84, 95-110. [CrossRef] [PubMed]

35. Zhang, X.C.; Wu, X.; Findley, S.; Wan, J.; Libault, M.; Nguyen, H.T.; Cannon, S.B.; Stacey, G. Molecular evolution of LysM type receptor-like kinases in plants. Plant Physiol. 2007, 144, 623-636. [CrossRef] [PubMed]

36. Ma, Q.H. Monocot chimeric jacalins: A novel subfamily of plant lectins. Crit. Rev. Biotechnol. 2014, 34, 300-306. [CrossRef] [PubMed]

37. Van Holle, S.; Van Damme, E.J.M. Distribution and evolution of the lectin family in soybean (Glycine max). Molecules 2015, 20, 2868-2891. [CrossRef] [PubMed]

38. Dang, L.; Van Damme, E.J.M. Genome-wide identification and domain organization of lectin domains in cucumber. Plant Physiol. Biochem. 2016, 108, 165-176. [CrossRef] [PubMed]

39. Eggermont, L.; Verstraeten, B.; Van Damme, E.J.M. Genome wide screening for lectin motifs in Arabidopsis thaliana. Plant Genome 2017. [CrossRef]

40. Percudani, R.; Montanini, B.; Ottonello, S. The anti-HIV cyanovirin-N domain is evolutionarily conserved and occurs as a protein module in eukaryotes. Proteins 2005, 60, 670-678. [CrossRef] [PubMed]

41. Peumans, W.J.; Fouquaert, E.; Jauneau, A.; Rougé, P.; Lannoo, N.; Hamada, H.; Alvarez, R.; Devreese, B.; Van Damme, E.J.M. The liverwort Marchantia polymorpha expresses orthologs of the fungal Agaricus bisporus agglutinin family. Plant Physiol. 2007, 144, 637-647. [CrossRef] [PubMed]

42. Bovi, M.; Carrizo, M.E.; Capaldi, S.; Perduca, M.; Chiarelli, L.R.; Galliano, M.; Monaco, H.L. Structure of a lectin with antitumoral properties in king bolete (Boletus edulis) mushrooms. Glycobiology 2011, 21, 1000-1009. [CrossRef] [PubMed]

43. Dang, L. Chimeric Lectins with Toxin Domains from Cucumber. Ph.D. Thesis, Ghent University, Ghent, Belgium, 2017.

44. Faruque, K.; Begam, R.; Deyholos, M.K. The Amaranthin-like lectin ( $L u A L L)$ genes of flax: A unique gene family with members inducible by defence hormones. Plant Mol. Biol. Rep. 2015, 33, 731-741. [CrossRef]

45. Sémon, M.; Wolfe, K.H. Consequences of genome duplication. Curr. Opin. Genet. Dev. 2007, 17, $505-512$. [CrossRef] [PubMed]

46. Wendel, J.F. Genome evolution in polyploids. Plant Mol. Biol. 2000, 42, 225-249. [CrossRef] [PubMed]

47. Schranz, E.M.; Mohammadin, S.; Edger, P.P. Ancient whole genome duplications, novelty and diversification: The WGD radiation lag-time model. Curr. Opin. Plant Biol. 2012, 15, 147-153. [CrossRef] [PubMed]

48. Van de Peer, Y.; Maere, S.; Meyer, A. The evolutionary significance of ancient genome duplications. Nat. Rev. Genet. 2009, 10, 725-732. [CrossRef] [PubMed]

49. Jiao, Y.; Wickett, N.J.; Ayyampalayam, S.; Chanderbali, A.S.; Landherr, L.; Ralph, P.E.; Tomsho, L.P.; Hu, Y.; Liang, H.; Soltis, P.S.; et al. Ancestral polyploidy in seed plants and angiosperms. Nature 2011, 473, 97-100. [CrossRef] [PubMed]

50. Blanc, G.; Hokamp, K.; Wolfe, K.H. A recent polyploidy superimposed on older large-scale duplications in the Arabidopsis genome. Genome Res. 2003, 13, 137-144. [CrossRef] [PubMed]

51. Tian, C.G.; Xiong, Y.Q.; Liu, T.Y.; Sun, S.H.; Chen, L.; Chen, M.S. Evidence for an ancient whole-genome duplication event in rice and other cereals. Yi Chuan Xue Bao 2005, 32, 519-527. [PubMed]

52. Yu, J.; Wang, J.; Lin, W.; Li, S.; Li, H.; Zhou, J.; Ni, P.; Dong, W.; Hu, S.; Zeng, C.; et al. The genomes of Oryza sativa: A history of duplications. PLoS Biol. 2005, 3, e38. [CrossRef] [PubMed] 
53. Paterson, A.H.; Bowers, J.E.; Chapman, B.A. Ancient polyploidization predating divergence of the cereals, and its consequences for comparative genomics. Proc. Natl. Acad. Sci. USA 2004, 101, 9903-9908. [CrossRef] [PubMed]

54. Schmutz, J.; Cannon, S.B.; Schlueter, J.; Ma, J.; Mitros, T.; Nelson, W.; Hyten, D.L.; Song, Q.; Thelen, J.J.; Cheng, J.; et al. Genome sequence of the palaeopolyploid soybean. Nature 2010, 463, 178-183. [CrossRef] [PubMed]

55. Shoemaker, R.C.; Schlueter, J.; Doyle, J.J. Paleopolyploidy and gene duplication in soybean and other legumes. Curr. Opin. Plant Biol. 2006, 9, 104-109. [CrossRef] [PubMed]

56. Huang, S.; Li, R.; Zhang, Z.; Li, L.; Gu, X.; Fan, W.; Lucas, W.J.; Wang, X.; Xie, B.; Ni, P.; et al. The genome of the cucumber, Cucumis sativus L. Nat. Genet. 2009, 41, 1275-1281. [CrossRef] [PubMed]

57. Cenci, A.; Combes, M.C.; Lashermes, P. Comparative sequence analyses indicate that Coffea (Asterids) and Vitis (Rosids) derive from the same paleo-hexaploid ancestral genome. Mol. Genet. Genom. 2010, 283, 493-501. [CrossRef] [PubMed]

58. Proost, S.; Van Bel, M.; Vaneechoutte, D.; Van de Peer, Y.; Inzé, D.; Mueller-Roeber, B.; Vandepoele, K. PLAZA 3.0: An access point for plant comparative genomics. Nucleic Acids Res. 2015, 974-981. [CrossRef] [PubMed]

59. Lam, B.C.H.; Blumwald, E. Domains as functional building blocks of plant proteins. Trends Plant Sci. 2002, 7 , 544-549. [CrossRef]

60. Fouquaert, E.; Peumans, W.J.; Vandekerckhove, T.T.M.; Ongenaert, M.; Van Damme, E.J.M. Proteins with an Euonymus lectin-like domain are ubiquitous in Embryophyta. BMC Plant Biol. 2009, 9, 136. [CrossRef] [PubMed]

61. De Schutter, K.; Tsaneva, M.; Kulkarni, S.R.; Rougé, P.; Vandepoele, K.; Van Damme, E.J.M. Evolutionary relationships and expression analysis of EUL domain proteins in rice (Oryza sativa). Rice 2017. [CrossRef]

62. Zhang, X.C.; Wang, Z.; Zhang, X.; Le, M.H.; Sun, J.; Xu, D.; Cheng, J.; Stacey, G. Evolutionary dynamics of protein domain architecture in plants. BMC Evol. Biol. 2012, 12, 6. [CrossRef] [PubMed]

63. Peumans, W.J.; Van Damme, E.J.M. Evolution of plant ribosome-inactivating proteins. In Plant Cell Monographs; Lord, J.M., Hartley, R.M., Eds.; Springer: New York, NY, USA, 2010; Volume 18, pp. 1-26.

64. Aspeborg, H.; Coutinho, P.M.; Wang, Y.; Brumer, H.; Henrissat, B. Evolution, substrate specificity and subfamily classification of glycoside hydrolase family 5 (GH5). BMC Evol. Biol. 2012, 12, 186. [CrossRef] [PubMed]

65. Olsnes, S. The history of ricin, abrin and related toxins. Toxicon 2004, 44, 361-370. [CrossRef] [PubMed]

66. Barbieri, L.; Valbonesi, P.; Gorini, P.; Pession, A.; Stirpe, F. Polynucleotide: Adenosine glycosidase activity of saporin-L1: effect on DNA, RNA and poly (A). Biochem. J. 1996, 319, 507-513. [CrossRef] [PubMed]

67. Bolognesi, A.; Bortolotti, M.; Maiello, S.; Battelli, M.; Polito, L. Ribosome-inactivating proteins from plants: A historical overview. Molecules 2016, 21, 1627. [CrossRef] [PubMed]

68. Cummings, R.D.; Etzler, M.E. R-type Lectins. In Essentials of Glycobiology, 2nd ed.; Varki, A., Cummings, R., Esko, J., Freeze, H., Stanley, P., Bertozzi, C., Hart, G., Etzler, M., Eds.; Cold Spring Harbor Laboratory: Cold Spring Harbor, NY, USA, 2009; pp. 403-414.

69. Vandenbussche, F.; Peumans, W.J.; Desmyter, S.; Proost, P.; Ciani, M.; Van Damme, E.J.M. The type-1 and type-2 ribosome-inactivating proteins from Iris confer transgenic tobacco plants local but not systemic protection against viruses. Planta 2004, 220, 211-221. [CrossRef] [PubMed]

70. Shahidi-Noghabi, S.; Van Damme, E.J.M.; Smagghe, G. Expression of Sambucus nigra agglutinin (SNA-I) from elderberry bark in transgenic tobacco plants results in enhanced resistance to different insect species. Transgenic Res. 2009, 18, 249-259. [CrossRef] [PubMed]

71. Wei, G.Q.; Liu, R.S.; Wang, Q.; Liu, W.Y. Toxicity of two type II ribosome-inactivating proteins (cinnamomin and ricin) to domestic silkworm larvae. Arch. Insect Biochem. Physiol. 2004, 57, 160-165. [CrossRef] [PubMed]

72. Schrot, J.; Weng, A.; Melzig, M.F. Ribosome-inactivating and related proteins. Toxins 2015, 7, $1556-1615$. [CrossRef] [PubMed]

73. Babu, M.; Griffiths, J.S.; Huang, T.S.; Wang, A. Altered gene expression changes in Arabidopsis leaf tissues and protoplasts in response to Plum pox virus infection. BMC Genom. 2008, 9, 325. [CrossRef] [PubMed]

74. Oda, A.; Sakuta, C.; Masuda, S.; Mizoguchi, T.; Kamada, H.; Satoh, S. Possible involvement of leaf gibberellins in the clock-controlled expression of XSP30, a gene encoding a xylem sap lectin, in cucumber roots. Plant Physiol. 2003, 133, 1779-1790. [CrossRef] [PubMed] 
75. Kittur, F.S.; Mangala, S.L.; Rus'd, A.A.; Kitaoka, M.; Tsujibo, H.; Hayashi, K. Fusion of family 2b carbohydrate-binding module increases the catalytic activity of a xylanase from Thermotoga maritima to soluble xylan. FEBS Lett. 2003, 549, 147-151. [CrossRef]

76. Mangala, S.L.; Kittur, F.S.; Nishimoto, M.; Sakka, K.; Ohmiya, K.; Kitaoka, M.; Hayashi, K. Fusion of family VI cellulose binding domains to Bacillus halodurans xylanase increases its catalytic activity and substrate-binding capacity to insoluble xylan. J. Mol. Catal. B. Enzym. 2003, 21, 221-230. [CrossRef]

77. Fujimoto, Z. Structure and function of carbohydrate-binding module families 13 and 42 of glycoside hydrolases, comprising a $\beta$-trefoil fold. Biosci. Biotechnol. Biochem. 2013, 77, 1363-1371. [CrossRef] [PubMed]

78. Lombard, V.; Ramulu, H.G.; Drula, E.; Coutinho, P.M.; Henrissat, B. The carbohydrate-active enzymes database (CAZy) in 2013. Nucleic Acids Res. 2014, 42, 490-495. [CrossRef] [PubMed]

79. Xu, G.; Ma, H.; Nei, M.; Kong, H. Evolution of F-box genes in plants: Different modes of sequence divergence and their relationships. Proc. Natl. Acad. Sci. USA 2009, 106, 835-840. [CrossRef] [PubMed]

80. Jain, M.; Nijhawan, A.; Arora, R.; Agarwal, P.; Ray, S.; Sharma, P.; Kapoor, S.; Tyagi, A.K.; Khurana, J.P. F-box proteins in rice. Genome-wide analysis, classification, temporal and spatial gene expression during panicle and seed development, and regulation by light and abiotic stress. Plant Physiol. 2007, 143, 1467-1483. [CrossRef] [PubMed]

81. Chen, Y.; Peumans, W.J.; Hause, B.; Bras, J.; Kumar, M.; Proost, P.; Barre, A.; Rougé, P.; Van Damme, E.J. M. Jasmonate methyl ester induces the synthesis of a cytoplasmic/nuclear chitooligosaccharide-binding lectin in tobacco leaves. FASEB J. 2002, 16, 905-907. [CrossRef] [PubMed]

82. Lannoo, N.; Vandenborre, G.; Miersch, O.; Smagghe, G.; Wasternack, C.; Peumans, W.J.; Van Damme, E.J. M. The jasmonate-induced expression of the Nicotiana tabacum leaf lectin. Plant Cell Physiol. 2007, 48, 1207-1218. [CrossRef] [PubMed]

83. Vandenborre, G.; Van Damme, E.J. M.; Smagghe, G. Nicotiana tabacum agglutinin expression in response to different biotic challengers. Arthropod. Plant Interact. 2009, 3, 193-202. [CrossRef]

84. Van Holle, S.; Smagghe, G.; Van Damme, E.J.M. Overexpression of Nictaba-like lectin genes from Glycine max confers tolerance toward Pseudomonas syringae infection, aphid infestation and salt stress in transgenic Arabidopsis plants. Front Plant Sci. 2016, 7, 1590. [CrossRef] [PubMed]

85. Zhang, C.; Shi, H.; Chen, L.; Wang, X.; Lü, B.; Zhang, S.; Liang, Y.; Liu, R.; Qian, J.; Sun, W.; You, Z.; Dong, H. Harpin-induced expression and transgenic overexpression of the phloem protein gene AtPP2-A1 in Arabidopsis repress phloem feeding of the green peach aphid Myzus persicae. BMC Plant Biol. 2011, 11, 11. [CrossRef] [PubMed]

86. Beneteau, J.; Renard, D.; Marché, L.; Douville, E.; Lavenant, L.; Rahbé, Y.; Dupont, D.; Vilaine, F.; Dinant, S. Binding properties of the $N$-acetylglucosamine and high-mannose $N$-glycan PP2-A1 phloem lectin in Arabidopsis. Plant Physiol. 2010, 153, 1345-1361. [CrossRef] [PubMed]

87. Delporte, A.; De Vos, W.H.; Van Damme, E.J. M. In vivo interaction between the tobacco lectin and the core histone proteins. J. Plant Physiol. 2014, 171, 1149-1156. [CrossRef] [PubMed]

88. Reuber, T.L.; Ausubel, F.M. Isolation of Arabidopsis genes that differentiate between resistance responses mediated by the RPS2 and RPM1 disease resistance genes. Plant Cell 1996, 8, 241-249. [CrossRef] [PubMed]

89. Ve, T.; Williams, S.J.; Kobe, B. Structure and function of Toll/interleukin-1 receptor/resistance protein (TIR) domains. Apoptosis 2015, 20, 250-261. [CrossRef] [PubMed]

90. Bai, C.; Sen, P.; Hofmann, K.; Ma, L.; Goebl, M.; Harper, J.; Elledge, S.J. SKP1 connects cell cycle regulators to the ubiquitin proteolysis machinery through a novel motif, the F-box. Cell 1996, 86, 263-274. [CrossRef]

91. Petroski, M.D.; Deshaies, R.J. Function and regulation of cullin-RING ubiquitin ligases. Nat. Rev. Mol. Cell Biol. 2005, 6, 9-20. [CrossRef] [PubMed]

92. Takahashi, N.; Kuroda, H.; Kuromori, T.; Hirayama, T.; Seki, M.; Shinozaki, K.; Shimada, H.; Matsui, M. Expression and interaction analysis of Arabidopsis Skp1-related genes. Plant Cell Physiol. 2004, 45, 83-91. [CrossRef] [PubMed]

93. Kipreos, E.T.; Pagano, M. The F-box protein family. Genome Biol. 2000, 1, reviews3002. [CrossRef] [PubMed]

94. Mizushima, T.; Yoshida, Y.; Kumanomidou, T.; Hasegawa, Y.; Suzuki, A.; Yamane, T.; Tanaka, K. Structural basis for the selection of glycosylated substrates by SCF(Fbs1) ubiquitin ligase. Proc. Natl. Acad. Sci. USA 2007, 104, 5777-5781. [CrossRef] [PubMed] 
95. Kuroda, H.; Yanagawa, Y.; Takahashi, N.; Horii, Y.; Matsui, M. A comprehensive analysis of interaction and localization of Arabidopsis SKP1-LIKE (ASK) and F-Box (FBX) proteins. PLoS ONE 2012, 7, e50009. [CrossRef] [PubMed]

96. Narsai, R.; Wang, C.; Chen, J.; Wu, J.; Shou, H.; Whelan, J. Antagonistic, overlapping and distinct responses to biotic stress in rice (Oryza sativa) and interactions with abiotic stress. BMC Genom. 2013, 14, 93. [CrossRef] [PubMed]

97. Stefanowicz, K.; Lannoo, N.; Zhao, Y.; Eggermont, L.; Van Hove, J.; Al Atalah, B.; Van Damme, E.J.M. Glycan-binding F-box protein from Arabidopsis thaliana protects plants from Pseudomonas syringae infection. BMC Plant Biol. 2016, 16, 213. [CrossRef] [PubMed]

98. Jia, F.; Wang, C.; Huang, J.; Yang, G.; Wu, C.; Zheng, C. SCF E3 ligase PP2-B11 plays a positive role in response to salt stress in Arabidopsis. J. Exp. Bot. 2015, 66, 4683-4697. [CrossRef] [PubMed]

99. Bouwmeester, K.; Govers, F. Arabidopsis L-type lectin receptor kinases: Phylogeny, classification, and expression profiles. J. Exp. Bot. 2009, 60, 4383-4396. [CrossRef] [PubMed]

100. Navarro-Gochicoa, M.T.; Camut, S.; Timmers, A.C. J.; Niebel, A.; Hervé, C.; Boutet, E.; Bono, J.-J.; Imbery, A.; Cullimore, J.V. Characterization of four lectin-like receptor kinases expressed in roots of Medicago truncatula. Structure, location, regulation of expression, and potential role in the symbiosis with Sinorhizobium meliloti. Plant Physiol. 2003, 133, 1893-1910. [CrossRef] [PubMed]

101. Brewin, N.J.; Kardailsky, I.V. Legume lectins and nodulation by Rhizobium. Trends Plant Sci. 1997, 2, 92-98. [CrossRef]

102. Frenzel, A.; Tiller, N.; Hause, B.; Krajinski, F. The conserved arbuscular mycorrhiza-specific transcription of the secretory lectin MtLec5 is mediated by a short upstream sequence containing specific protein binding sites. Planta 2006, 224, 792-800. [CrossRef] [PubMed]

103. Wang, Y.; Cordewener, J.H.G.; America, A.H.P.; Shan, W.X.; Bouwmeester, K.; Govers, F. Arabidopsis lectin receptor kinases LecRK-IX.1 and LecRK-IX.2 are functional analogs in regulating Phytophthora resistance and plant cell death. Mol. Plant Microbe Interact. 2015, 28, 1032-1048. [CrossRef] [PubMed]

104. Bouwmeester, K.; Han, M.; Blanco-Portales, R.; Song, W.; Weide, R.; Guo, L.Y.; van der Vossen, E.A.G.; Govers, F. The Arabidopsis lectin receptor kinase LecRK-I.9 enhances resistance to Phytophthora infestans in Solanaceous plants. Plant Biotechnol. J. 2014, 12, 10-16. [CrossRef] [PubMed]

105. Kanzaki, H.; Saitoh, H.; Takahashi, Y.; Berberich, T.; Ito, A.; Kamoun, S.; Terauchi, R. NbLRK1, a lectin-like receptor kinase protein of Nicotiana benthamiana, interacts with Phytophthora infestans INF1 elicitin and mediates INF1-induced cell death. Planta 2008, 228, 977-987. [CrossRef] [PubMed]

106. Gouget, A.; Senchou, V.; Govers, F.; Sanson, A.; Barre, A.; Rougé, P.; Pont-Lezica, R.; Canut, H. Lectin receptor kinases participate in protein-protein interactions to mediate plasma membrane-cell wall adhesions in Arabidopsis. Plant Physiol. 2006, 140, 81-90. [CrossRef] [PubMed]

107. Wu, T.; Wang, R.; Xu, X.; He, X.; Sun, B.; Zhong, Y.; Liang, Z.; Luo, S.; Lin, Y. Cucumis sativus L-type lectin receptor kinase (CsLecRK) gene family response to Phytophthora melonis, Phytophthora capsici and water immersion in disease resistant and susceptible cucumber cultivars. Gene 2014, 549, 214-222. [CrossRef] [PubMed]

108. Huang, P.; Ju, H.W.; Min, J.H.; Zhang, X.; Kim, S.H.; Yang, K.Y.; Kim, C.S. Overexpression of L-type lectin-like protein kinase 1 confers pathogen resistance and regulates salinity response in Arabidopsis thaliana. Plant Sci. 2013, 203-204, 98-106. [CrossRef] [PubMed]

109. Gilardoni, P.A.; Hettenhausen, C.; Baldwin, I.T.; Bonaventure, G. Nicotiana attenuata LECTIN RECEPTOR KINASE1 suppresses the insect-mediated inhibition of induced defense responses during Manduca sexta herbivory. Plant Cell 2011, 23, 3512-3532. [CrossRef] [PubMed]

110. Desclos-Theveniau, M.; Arnaud, D.; Huang, T.Y.; Lin, G.J. C.; Chen, W.Y.; Lin, Y.C.; Zimmerli, L. The Arabidopsis lectin receptor kinase LecRK-V.5 represses stomatal immunity induced by Pseudomonas syringae pv. tomato DC3000. PLoS Pathog. 2012, 8, e1002513. [CrossRef] [PubMed]

111. Singh, P.; Kuo, Y.C.; Mishra, S.; Tsai, C.H.; Chien, C.C.; Chen, C.W.; Desclos-Theveniau, M.; Chu, P.W.; Schulze, B.; Chinchilla, D.; et al. The lectin receptor kinase-VI.2 is required for priming and positively regulates Arabidopsis pattern-triggered immunity. Plant Cell 2012, 24, 1256-1270. [CrossRef] [PubMed]

112. Vaid, N.; Pandey, P.; Srivastava, V.K.; Tuteja, N. Pea lectin receptor-like kinase functions in salinity adaptation without yield penalty, by alleviating osmotic and ionic stresses and upregulating stress-responsive genes. Plant Mol. Biol. 2015, 88, 193-206. [CrossRef] [PubMed] 
113. Choi, J.; Tanaka, K.; Cao, Y.; Qi, Y.; Qiu, J.; Liang, Y.; Lee, S.Y.; Stacey, G. Identification of a plant receptor for extracellular ATP. Science 2014, 343, 290-294. [CrossRef] [PubMed]

114. Cao, Y.; Tanaka, K.; Nguyen, C.T.; Stacey, G. Extracellular ATP is a central signaling molecule in plant stress responses. Curr. Opin. Plant Biol. 2014, 20, 82-87. [CrossRef] [PubMed]

115. Shiu, S.; Karlowski, W.; Pan, R. Comparative analysis of the receptor-like kinase family in Arabidopsis and rice. Plant Cell 2004, 16, 1220-1234. [CrossRef] [PubMed]

116. Kachroo, A.; Schopfer, C.R.; Nasrallah, M.E.; Nasrallah, J.B. Allele-specific receptor-ligand interactions in Brassica self-incompatibility. Science 2001, 293, 1824-1826. [CrossRef] [PubMed]

117. Kim, Y.T.; Oh, J.; Kim, K.H.; Uhm, J.Y.; Lee, B.M. Isolation and characterization of NgRLK1, a receptor-like kinase of Nicotiana glutinosa that interacts with the elicitin of Phytophthora capsici. Mol. Biol. Rep. 2010, 37, 717-727. [CrossRef] [PubMed]

118. Lenka, S.K.; Lohia, B.; Kumar, A.; Chinnusamy, V.; Bansal, K.C. Genome-wide targeted prediction of ABA responsive genes in rice based on over-represented cis-motif in co-expressed genes. Plant Mol. Biol. 2009, 69, 261-271. [CrossRef] [PubMed]

119. Bonaventure, G. The Nicotiana attenuata LECTIN RECEPTOR KINASE 1 is involved in the perception of insect feeding. Plant Signal Behav. 2011, 6, 2060-2063. [CrossRef] [PubMed]

120. Xu, E.; Vaahtera, L.; Brosché, M. Roles of defense hormones in the regulation of ozone-induced changes in gene expression and cell death. Mol. Plant 2015, 8, 1776-1794. [CrossRef] [PubMed]

121. Sanabria, N.; Goring, D.; Nürnberger, T.; Dubery, I. Self/nonself perception and recognition mechanisms in plants: A comparison of self-incompatibility and innate immunity. New Phytol. 2008, 178, 503-514. [CrossRef] [PubMed]

122. Blaum, B.S.; Mazzotta, S.; Nöldeke, E.R.; Halter, T.; Madlung, J.; Kemmerling, B.; Stehle, T. Structure of the pseudokinase domain of BIR2, a regulator of BAK1-mediated immune signaling in Arabidopsis. J. Struct. Biol. 2014, 186, 112-121. [CrossRef] [PubMed]

123. Chen, L.J.; Wuriyanghan, H.; Zhang, Y.Q.; Duan, K.X.; Chen, H.W.; Li, Q.T.; Lu, X.; He, S.J.; Ma, B.; Zhang, W.K.; et al. An S-domain receptor-like kinase, OsSIK2, confers abiotic stress tolerance and delays dark-induced leaf senescence in rice. Plant Physiol. 2013, 163, 1752-1765. [CrossRef] [PubMed]

124. Cheng, X.; Wu, Y.; Guo, J.; Du, B.; Chen, R.; Zhu, L.; He, G. A rice lectin receptor-like kinase that is involved in innate immune responses also contributes to seed germination. Plant J. 2013, 76, 687-698. [CrossRef] [PubMed]

125. Liu, Y.; Wu, H.; Chen, H.; Liu, Y.; He, J.; Kang, H.; Sun, Z.; Pan, G.; Wang, Q.; Hu, J.; et al. A gene cluster encoding lectin receptor kinases confers broad-spectrum and durable insect resistance in rice. Nat. Biotechnol. 2014, 33, 301-305. [CrossRef] [PubMed]

126. Chen, X.; Shang, J.; Chen, D.; Lei, C.; Zou, Y.; Zhai, W.; Liu, G.; Xu, J.; Ling, Z.; Cao, G.; et al. A B-lectin receptor kinase gene conferring rice blast resistance. Plant J. 2006, 46, 794-804. [CrossRef] [PubMed]

127. Woloshuk, C.P.; Meulenhoff, J.S.; Sela-Buurlage, M.B.; van den Elzen, P.J.M.; Cornelissen, B.J.C. Pathogen-induced proteins with inhibitory activity toward Phytophthora infestans. Plant Cell 1991, 3, 619-628. [CrossRef] [PubMed]

128. Van Loon, L.C.; Rep, M.; Pieterse, C.M.J. Significance of inducible defense-related proteins in infected plants. Annu. Rev. Phytopathol. 2006, 44, 135-162. [CrossRef] [PubMed]

129. Schaper, E.; Anisimova, M. The evolution and function of protein tandem repeats in plants. New Phytol. 2015, 206, 397-410. [CrossRef] [PubMed]

130. Hammond-Kosack, K.E.; Jones, J.D.G. Plant disease resistance genes. Annu. Rev. Plant Physiol. Plant Mol. Biol. 1997, 48, 575-607. [CrossRef] [PubMed]

131. Peumans, W.J.; Barre, A.; Bras, J.; Rougé, P.; Proost, P.; Van Damme, E.J.M. The liverwort contains a lectin that is structurally and evolutionary related to the monocot mannose-binding lectins. Plant Physiol. 2002, 129, 1054-1065. [CrossRef] [PubMed]

132. Lannoo, N.; Van Damme, E.J.M. Lectin domains at the frontiers of plant defense. Front Plant Sci. 2014, 5, 397. [CrossRef] [PubMed]

133. Xing, L.; Li, J.; Xu, Y.; Xu, Z.; Chong, K. Phosphorylation modification of wheat lectin VER2 is associated with vernalization-induced $O-G l c N A c$ signaling and intracellular motility. PLoS ONE 2009, 4, e4854. [CrossRef] [PubMed] 
134. Zhang, W.; Peumans, W.J.; Barre, A.; Astoul, C.H.; Rovira, P.; Rougé, P.; Proost, P.; Truffa-Bachi, P.; Jalali, A.A.; Van Damme, E.J.M. Isolation and characterization of a jacalin-related mannose-binding lectin from salt-stressed rice (Oryza sativa) plants. Planta 2000, 210, 970-978. [PubMed]

135. Al Atalah, B.; Smagghe, G.; Van Damme, E.J.M. Orysata, a jacalin-related lectin from rice, could protect plants against biting-chewing and piercing-sucking insects. Plant Sci. 2014, 221-222, 21-28. [CrossRef] [PubMed]

136. Lee, R.H.; Wang, C.H.; Huang, L.T.; Chen, S.C. Leaf senescence in rice plants: Cloning and characterization of senescence up-regulated genes. J. Exp. Bot. 2001, 52, 1117-1121. [CrossRef] [PubMed]

137. Qin, Q.M.; Zhang, Q.; Zhao, W.S.; Wang, Y.Y.; Peng, Y.L. Identification of a lectin gene induced in rice in response to Magnaporthe grisea infection. Acta. Bot. Sin. 2003, 23, 799-810.

138. De Souza Filho, G.A.; Ferreira, B.S.; Dias, J.M.; Queiroz, K.S.; Branco, A.T.; Bressan-Smith, R.E.; Oliveira, J.G.; Garcia, A.B. Accumulation of SALT protein in rice plants as a response to environmental stresses. Plant Sci. 2003, 164, 623-628. [CrossRef]

139. Patishtan, J.; Hartley, T.N.; Fonseca de Carvalho, R.; Maathuis, F.J. Genome wide association studies to identify rice salt-tolerance markers. Plant Cell Environ 2017, in press.

140. He, X.; Li, L.; Xu, H.; Xi, J.; Cao, X.; Xu, H.; Rong, S.; Dong, Y.; Wang, C.; Chen, R.; et al. A rice jacalin-related mannose-binding lectin gene, OsJRL, enhances Escherichia coli viability under high salinity stress and improves salinity tolerance of rice. Plant Biol. 2017, 19, 257-267. [CrossRef] [PubMed]

141. Shinjo, A.; Araki, Y.; Hirano, K.; Arie, T.; Ugaki, M.; Teraoka, T. Transgenic rice plants that over-express the mannose-binding rice lectin have enhanced resistance to rice blast. J. Gen. Plant Pathol. 2011, 77, 85-92. [CrossRef]

142. Yamaji, Y.; Maejima, K.; Ozeki, J.; Komatsu, K.; Shiraishi, T.; Okano, Y.; Himeno, M.; Sugawara, K.; Neriya, Y.; Minato, N.; et al. Lectin-mediated resistance impairs plant virus infection at the cellular level. Plant Cell 2012, 24, 778-793. [CrossRef] [PubMed]

143. Xiao, J.; Li, C.; Xu, S.; Xing, L.; Xu, Y.; Chong, K. AtJAC1 regulates nuclear accumulation of GRP7, influencing RNA processing of FLC antisense transcripts and flowering time in Arabidopsis. Plant Physiol. 2015, 169, 2102-2117. [CrossRef] [PubMed]

144. Chisholm, S.T.; Parra, M.A.; Anderberg, R.J.; Carrington, J.C. Arabidopsis RTM1 and RTM2 genes function in phloem to restrict long-distance movement of tobacco etch virus. Plant Physiol. 2001, 127, 1667-1675. [CrossRef] [PubMed]

145. Revers, F.; Guiraud, T.; Houvenaghel, M.-C.; Mauduit, T.; Le Gall, O.; Candresse, T. Multiple resistance phenotypes to lettuce mosaic virus among Arabidopsis thaliana accessions. MPMI Mol. Plant Microbe Interact. 2003, 16, 608-616. [CrossRef] [PubMed]

146. Decroocq, V.; Sicard, O.; Alamillo, J.M.; Lansac, M.; Eyquard, J.P.; García, J.A.; Candresse, T.; Le Gall, O.; Revers, F. Multiple resistance traits control Plum pox virus infection in Arabidopsis thaliana. MPMI Mol. Plant Microbe Interact. 2006, 19, 541-549. [CrossRef] [PubMed]

147. Van der Biezen, E.A.; Jones, J.D.G. The NB-ARC domain: A novel signalling motif shared by plant resistance gene products and regulators of cell death in animals. Curr. Biol. 1998, 8, R226-R228. [CrossRef]

148. Johnson, J.E.; Goulding, R.E.; Ding, Z.; Partovi, A.; Anthony, K.V.; Beaulieu, N.; Tazmini, G.; Cornell, R.B.; Kay, R.J. Differential membrane binding and diacylglycerol recognition by C1 domains of RasGRPs. Biochem. J. 2007, 406, 223-236. [CrossRef] [PubMed]

149. Valster, A.H.; Hepler, P.K.; Chernoff, J. Plant GTPases: The Rhos in bloom. Trends Cell Biol. 2000, 10, 141-146. [CrossRef]

150. Zhang, X.C.; Cannon, S.B.; Stacey, G. Evolutionary genomics of LysM genes in land plants. BMC Evol. Biol. 2009, 9, 183. [CrossRef] [PubMed]

151. Buist, G.; Steen, A.; Kok, J.; Kuipers, O.P. LysM, a widely distributed protein motif for binding to (peptido)glycans. Mol. Microbiol. 2008, 68, 838-847. [CrossRef] [PubMed]

152. Gust, A.A.; Willmann, R.; Desaki, Y.; Grabherr, H.M.; Nürnberger, T. Plant LysM proteins: Modules mediating symbiosis and immunity. Trends Plant Sci. 2012, 17, 495-502. [CrossRef] [PubMed]

153. Shimizu, T.; Nakano, T.; Takamizawa, D.; Desaki, Y.; Ishii-Minami, N.; Nishizawa, Y.; Minami, E.; Okada, K.; Yamane, H.; Kaku, H.; et al. Two LysM receptor molecules, CEBiP and OsCERK1, cooperatively regulate chitin elicitor signaling in rice. Plant J. 2010, 64, 204-214. [CrossRef] [PubMed] 
154. Petutschnig, E.K.; Jones, A.M.E.; Serazetdinova, L.; Lipka, U.; Lipka, V. The Lysin Motif Receptor-like Kinase (LysM-RLK) CERK1 is a major chitin-binding protein in Arabidopsis thaliana and subject to chitin-induced phosphorylation. J. Biol. Chem. 2010, 285, 28902-28911. [CrossRef] [PubMed]

155. Radutoiu, S.; Madsen, L.H.; Madsen, E.B.; Felle, H.H.; Umehara, Y.; Grønlund, M.; Sato, S.; Nakamura, Y.; Tabata, S.; Sandal, N.; Stougaard, J. Plant recognition of symbiotic bacteria requires two LysM receptor-like kinases. Nature 2003, 425, 585-592. [CrossRef] [PubMed]

156. Knogge, W.; Scheel, D. LysM receptors recognize friend and foe. Proc. Natl. Acad. Sci. USA 2006, 103, 10829-10830. [CrossRef] [PubMed]

157. Limpens, E.; Franken, C.; Smit, P.; Willemse, J.; Bisseling, T.; Geurts, R. LysM domain receptor kinases regulating rhizobial Nod factor-induced infection. Science 2003, 302, 630-633. [CrossRef] [PubMed]

158. Indrasumunar, A.; Kereszt, A.; Searle, I.; Miyagi, M.; Li, D.; Nguyen, C.D.T.; Men, A.; Carroll, B.J.; Gresshoff, P.M. Inactivation of duplicated nod factor receptor 5 (NFR5) genes in recessive loss-of-function non-nodulation mutants of allotetraploid soybean (Glycine max L. Merr.). Plant Cell Physiol. 2010, 51, 201-214. [CrossRef] [PubMed]

159. Indrasumunar, A.; Searle, I.; Lin, M.H.; Kereszt, A.; Men, A.; Carroll, B.J.; Gresshoff, P.M. Nodulation factor receptor kinase $1 \alpha$ controls nodule organ number in soybean (Glycine max L. Merr). Plant J. 2011, 65, 39-50. [CrossRef] [PubMed]

160. Amor, B.B.; Shaw, S.L.; Oldroyd, G.E.D.; Maillet, F.; Penmetsa, R.V.; Cook, D.; Long, S.R.; Dénarié, J.; Gough, C. The NFP locus of Medicago truncatula controls an early step of Nod factor signal transduction upstream of a rapid calcium flux and root hair deformation. Plant J. 2003, 34, 495-506. [CrossRef] [PubMed]

161. Madsen, E.B.; Madsen, L.H.; Radutoiu, S.; Olbryt, M.; Rakwalska, M.; Szczyglowski, K.; Sato, S.; Kaneko, T.; Tabata, S.; Sandal, N.; et al. A receptor kinase gene of the LysM type is involved in legume perception of rhizobial signals. Nature 2003, 425, 637-640. [CrossRef] [PubMed]

162. Neuhaus, J.M.; Fritig, B.; Linthorst, H.J.M.; Meins, F.; Mikkelsen, J.D.; Ryals, J. A revised nomenclature for chitinase genes. Plant Mol. Biol. Rep. 1996, 14, 102-104. [CrossRef]

163. Ludvigsen, S.; Poulsen, F.M. Three-dimensional structure in solution of barwin, a protein from barley seed. Biochemistry 1992, 31, 8783-8789. [CrossRef] [PubMed]

164. Rao, M.V.; Lee, H.I.; Davis, K.R. Ozone-induced ethylene production is dependent on salicylic acid, and both salicylic acid and ethylene act in concert to regulate ozone-induced cell death. Plant J. 2002, 32, 447-456. [CrossRef] [PubMed]

165. Mukherjee, A.K.; Carp, M.J.; Zuchman, R.; Ziv, T.; Horwitz, B. A.; Gepstein, S. Proteomics of the response of Arabidopsis thaliana to infection with Alternaria brassicicola. J. Proteom. 2010, 73, 709-720. [CrossRef] [PubMed]

166. Thomma, B.P.H.J.; Eggermont, K.; Penninckx, I.A.M.A.; Mauch-Mani, B.; Vogelsang, R.; Cammue, B.P.A.; Broekaert, W.F. Separate jasmonate-dependent and salicylate-dependent defense-response pathways in Arabidopsis are essential for resistance to distinct microbial pathogens. Proc. Natl. Acad. Sci. USA 1998, 95, 15107-15111. [CrossRef] [PubMed]

167. Seo, P.J.; Lee, A.K.; Xiang, F.; Park, C.M. Molecular and functional profiling of Arabidopsis pathogenesis-related genes: Insights into their roles in salt response of seed germination. Plant Cell Physiol. 2008, 49, 334-344. [CrossRef] [PubMed]

168. Potter, S.; Uknes, S.; Lawton, K.; Winter, A.M.; Chandler, D.; DiMaio, J.; Novitzky, R.; Ward, E.; Ryals, J. Regulation of a hevein-like gene in Arabidopsis. MPMI Mol. Plant Microbe Interact. 1993, 6, 680-685. [CrossRef] [PubMed]

169. Thomma, B.P.; Eggermont, K.; Tierens, K.F.; Broekaert, W.F. Requirement of functional ethylene-insensitive 2 gene for efficient resistance of Arabidopsis to infection by Botrytis cinerea. Plant Physiol. 1999, 121, 1093-1102. [CrossRef] [PubMed]

170. de A Gerhardt, L.B.; Sachetto-Martins, G.; Contarini, M.G.; Sandroni, M.; de P Ferreira, R.; de Lima, V.M.; Cordeiro, M.C.; de Oliveira, D.E.; Margis-Pinheiro, M. Arabidopsis thaliana class IV chitinase is early induced during the interaction with Xanthomonas campestris. FEBS Lett. 1997, 419, 69-75. [CrossRef]

171. de A Gerhardt, L.B.; Magioli, C.; Perez, A.B.U.C.M.; Margis, R.; Sachetto-Martins, G.; Margis-Pinheiro, M. AtchitIV gene expression is stimulated under abiotic stresses and is spatially and temporally regulated during embryo development. Genet. Mol. Biol. 2004, 27, 118-123. [CrossRef]

172. Gijzen, M.; Kuflu, K.; Qutob, D.; Chernys, J.T. A class I chitinase from soybean seed coat. J. Exp. Bot. 2001, 52, 2283-2289. [CrossRef] [PubMed] 
173. Bagnaresi, P.; Biselli, C.; Orrù, L.; Urso, S.; Crispino, L.; Abbruscato, P.; Piffanelli, P.; Lupotto, E.; Cattivelli, L.; Valè, G. Comparative transcriptome profiling of the early response to Magnaporthe oryzae in durable resistant vs susceptible rice (Oryza sativa L.) genotypes. PLoS ONE 2012, 7, e51609. [CrossRef] [PubMed]

174. Nishizawa, Y.; Nishio, Z.; Nakazono, K.; Soma, M.; Nakajima, E.; Ogaki, M.; Hibi, T. Enhanced resistance to blast (Magnaporthe grisea) in transgenic japonica rice by constitutive expression of rice chitinase. Theor. Appl. Genet. 1999, 99, 383-390. [CrossRef] [PubMed]

175. Kovács, G.; Sági, L.; Jacon, G.; Arinaitwe, G.; Busogoro, J.P.; Thiry, E.; Strosse, H.; Swennen, R.; Remy, S. Expression of a rice chitinase gene in transgenic banana ('Gros Michel', AAA genome group) confers resistance to black leaf streak disease. Transgenic Res. 2013, 22, 117-130. [CrossRef] [PubMed]

176. Huang, X.; Wang, J.; Du, Z.; Zhang, C.; Li, L.; Xu, Z. Enhanced resistance to stripe rust disease in transgenic wheat expressing the rice chitinase gene RC24. Transgenic Res. 2013, 22, 939-947. [CrossRef] [PubMed]

177. Kawahara, Y.; de la Bastide, M.; Hamilton, J.P.; Kanamori, H.; McCombie, W.R.; Ouyang, S.; Schwartz, D.C.; Tanaka, T.; Wu, J.; Zhou, S.; et al. Improvement of the Oryza sativa Nipponbare reference genome using next generation sequence and optical map data. Rice 2013, 6, 4. [CrossRef] [PubMed]

178. Quevillon, E.; Silventoinen, V.; Pillai, S.; Harte, N.; Mulder, N.; Apweiler, R.; Lopez, R. InterProScan: protein domains identifier. Nucleic Acids Res. 2005, 33, W116-W120. [CrossRef] [PubMed]

179. Petersen, T.N.; Brunak, S.; von Heijne, G.; Nielsen, H. SignalP 4.0: Discriminating signal peptides from transmembrane regions. Nat. Methods 2011, 8, 785-786. [CrossRef] [PubMed]

180. Krogh, A.; Larsson, B.; von Heijne, G.; Sonnhammer, E.L.L. Predicting transmembrane protein topology with a hidden Markov model: Application to complete genomes. J. Mol. Biol. 2001, 305, 567-580. [CrossRef] [PubMed]

181. Edgar, R.C. MUSCLE: Multiple sequence alignment with high accuracy and high throughput. Nucleic Acids Res. 2004, 32, 1792-1797. [CrossRef] [PubMed]

182. Kumar, S.; Stecher, G.; Tamura, K. Molecular Evolutionary Genetics Analysis version 7.0 for bigger datasets. Mol. Biol. Evol. 2016, 33, 1870-1874. [CrossRef] [PubMed]

183. Capella-Gutiérrez, S.; Silla-Martínez, J.M.; Gabaldón, T. trimAl: A tool for automated alignment trimming in large-scale phylogenetic analyses. Bioinformatics 2009, 25, 1972-1973. [CrossRef] [PubMed]

184. Stamatakis, A. RAxML version 8: A tool for phylogenetic analysis and post-analysis of large phylogenies. Bioinformatics 2014, 30, 1312-1313. [CrossRef] [PubMed]

185. Ruprecht, C.; Proost, S.; Hernandez-Coronado, M.; Ortiz-Ramirez, C.; Lang, D.; Rensing, S.A.; Becker, J.D.; Vandepoele, K.; Mutwil, M. Phylogenomic analysis of gene co-expression networks reveals evolution of functional modules. Plant J. 2017, 90, 447-465. [CrossRef] [PubMed]

186. Ruprecht, C.; Vaid, N.; Proost, S.; Persson, S.; Mutwil, M. Beyond genomics: Studying evolution with gene coexpression networks. Trends Plant Sci. 2017, 22, 298-307. [CrossRef] [PubMed] 